\title{
A narratividade da cantora-atriz Martha Herr em Cantos, de Tim Rescala
}

\author{
Fausto Borém \\ Universidade Federal de Minas Gerais \\ faustoborem@gmail.com \\ Ilza Nogueira \\ Universidade Federal da Paraíba \\ nogueira.ilza@gmail.com
}

Resumo: Primeiro de uma série de três estudos de caso sobre a narratividade na performance da cantoraatriz Martha Herr (1952-2015), o presente trabalho analisa Cantos (1994), para voz sem acompanhamento, de Tim Rescala (1994), recorrendo ao $m A A V m$ (Método de Análise de Áudios e Vídeos de Música) de Fausto Borém (2016), a teorias da narratividade em música e da psicologia social. Inicialmente, analisamos o binômio texto-música na partitura. Posteriormente, na condição de espectadores informados, observamos o trinômio (con)texto-som-imagem em um vídeo profissional da cantora (HERR; RESCALA, 2008), que fez parte do $42^{\circ}$ Festival de Música Nova (2007, São Paulo). Finalmente, analisamos as interrelações entre composição e performance. É notável como Martha Herr transcende a interpretação musical stricto sensu da partitura ao planejar e construir meticulosamente um discurso narrativo hipertextual, representando distintas personagens (que incluem sua própria persona como personagem-narradora). A construção da interpretação narrativa realiza-se através de: (1) personalização dos motivos, (2) adição de novo efeito vocal, (3) interação com objetos de cena e iluminação de palco, (4) trasladação, contração e ampliação de cinesfera e (5) criação de contexto cênico. As contribuições de Martha resultam de um meticuloso planejamento e construção de uma performance carregada de expressões faciais e gestos com significados subliminares. Assim, ela extrapola o conteúdo composicional de Cantos, revelando uma habilidade peculiar de narrar e instigar ideias vertiginosamente, fruto de imaginação, versatilidade e integração entre os estratos do (con)texto, do som e da imagem.

Palavras-chave: Narratividade na performance musical. Martha Herr. Psicologia social e música. Análise de vídeo de música. Música cênica de Tim Rescala.

\section{The Narrativity of Singer-Actress Martha Herr in Cantos, by Tim Rescala}

Abstract: First of a series of three case studies on the narrative performance of singer-actress Martha Herr (1952-2015), this study analyses Cantos (1994), for solo voice, by Tim Rescala (1994), resorting to $m A A V m$ (Method for the Analysis of Audios and Videos of Music) by Fausto Borém (2016) and theories of music narrativity interacting with concepts from social psychology. Initially, we analyzed the text-music binomial in the score. Subsequently, as informed spectators, we observed the (con)text-sound-image trinomial in a professional video (HERR; RESCALA, 2008), which was part of the 42nd Festival de Música Nova (2007, São Paulo). Finally, we analyzed the interrelationships between composition and performance. We observed that Martha Herr transcends the stricto sensu musical interpretation of the score, planning and constructing meticulously a hypertextual narrative discourse with multiple characters (including her own persona as narrator). This is achieved by means of: (1) a personal interpretation of the musical motives identified in the piece, (2) the addition of a new vocal effect, (3) interaction with props and stage lighting, (4) translation, retraction and extension of her kinesphere, and (5) creation of a theatrical context. Martha's contributions result from a meticulous planning and construction of a performance charged with distinctive facial expressions and gestures with subliminal meanings. Thus, she extrapolates the compositional content showing a peculiar ability to narrate and instigate ideas dizzyingly, which results from imagination, versatility, and integration between the strata of (con)text, sound, and image.

Keywords: Narrativity in music performance. Performance by singer-actress Martha Herr. Social psychology and music. Analysis of music videos. Theatrical music by Tim Rescala. 


\section{1 - Introdução ao estudo analítico}

O objetivo do estudo analítico ora iniciado com a peça Cantos (1994) de Tim Rescala $^{1}$ é analisar a narratividade da cantora-atriz Martha Herr ${ }^{2}$ no recital solo Vozes em conversa, gravado ao vivo em vídeo e exibido pela Sesc TV em 2008, como parte do $42^{\circ}$ Festival de Música Nova (São Paulo e Santos, 2007). Nesse seu último recital documentado profissionalmente, Martha Herr ocupa sozinha o palco, contrapondo, justapondo e integrando sua voz a objetos de cena, iluminação de palco e, às vezes, produzindo sons a partir de instrumentos musicais ou objetos sonoros que ela mesma toca ou aciona. O programa gravado teve direção cênica e iluminação de Iacov Hilel, e direção de fotografia de Carlos Travaglia.

Para que o leitor possa acompanhar confortavelmente a análise das três obras selecionadas deste repertório, nós as recortamos e publicamos na plataforma YouTube ${ }^{3}$. Assim, transformamos essas gravações em nossas fontes primárias de forma que

\footnotetext{
${ }^{1}$ O multifário Tim (Luís Augusto) Rescala (compositor, cantor, instrumentista, arranjador, dramaturgo, ator e humorista) licenciou-se em Música pela Universidade Federal do Estado do Rio de Janeiro - UNIRIO (1983), tendo estudado contraponto, arranjo e composição com Hans-Joachim Koellreutter entre 1979 e 1983. Como ator, protagonizou papéis em filmes, teatro e, especialmente, na televisão, atuando como o Professor Mesquita (um professor de música) e Capilé Sorriso (um humorista "sem graça") na Escolinha do Professor Raimundo, programa do ator-escritor Chico Anísio (SIDNEY, 2016). Tim Rescala recebeu muitos prêmios como compositor, e suas obras são frequentemente realizadas no país e no exterior. A grande afinidade com a música cênica se reflete na sua produção de óperas e musicais (RESCALA, 2019b): 3 musicais para adultos, 6 musicais para crianças (sendo 3 em parceria com José Augusto Brant), 2 óperas para adultos (sendo uma com Arrigo Barnabé e Guto Lacaz), 3 óperas infantis e 2 operetas. Sua obra sinfônica e de câmara, da qual Cantos faz parte, é marcada por uma forte vocação teatral, incluindo trilhas sonoras para peças de teatro e filmes, obras para exposição de artes visuais, obras para atores e fita magnética e obras com recursos cênicos (RESCALA, 2019a).

${ }^{2}$ Norte-americana de nascimento e brasileira de coração, a soprano Martha Herr (Chicago, 1952 - São Paulo, 2015) atuou em várias frentes profissionais, tendo estabelecido marcos para a performance e o ensino da música para voz. Cantora-atriz e maestrina, ela recebeu o Prêmio de Cantora do Ano de 1990 pela APCA (Associação Paulista de Críticos de Arte) e o Prêmio Carlos Gomes de Destaque Vocal (Secretaria de Cultura do Estado de São Paulo) em 1998 (SAMPAIO, 2015). Martha estreou mais de 100 obras no Brasil, incluindo o protagonismo na ópera Olga de Jorge Antunes, em 2006. Em entrevista à soprano e musicóloga Patricia Caicedo, ela declara: "I performed a lot more Brazilian music than many Brazilians!" [Cantei muito mais música brasileira do que muitos brasileiros.]" (HERR; CAICEDO, 2010, [2:47]). Como professora, dedicou-se ao ensino do canto na Unesp, onde, após aposentar-se, continuou trabalhando como voluntária por mais de uma década. Como pesquisadora, iniciou, liderou e consolidou uma longamente esperada revisão nacional das normas de pronúncia do português cantado (HERR et al., 2008; HERR; KAYAMA; MATTOS, 2008; HERR, 2007; HERR, 2004; HERR, 2003).

${ }^{3}$ Cantos de Tim Rescala (In: https://youtu.be/fXAuku7alIU), Ir alten Weib de Gilberto Mendes (In: https://youtu.be/A5nQBP3ldnA) e Marthóperas de Eduardo Guimarães Álvares (In: https://youtu.be/e5fxwbjt1zY).
} 
os timings ${ }^{4}$, que servem para localizar e apreciar elementos significativos da música analisados em cada obra, comecem da marca [0:00].

O delineamento metodológico utilizado incluiu três etapas e diversos procedimentos interdisciplinares. Inicialmente, após observar as características cênicomusicais de Martha Herr nesse recital, escolhemos as peças em função de seus potenciais para constituírem estudos de caso singulares $^{5}$. Em uma segunda etapa, analisamos elementos do binômio texto-música e dados deixados pelos compositores nas partituras (as quais continham anotações de próprio punho de Martha Herr ${ }^{6}$ ). Estas etapas iniciais nos permitiram retornar aos vídeos para compararmos as partituras com as realizações de Martha. Assim, foram detectadas ênfases e contradições no trinômio (con)texto-somimagem, que conduziram a compreensão da performance de Martha Herr como um discurso essencialmente narrativo. Os dados textuais, sonoros e imagéticos formam a base para a construção dos MaPAs (Mapas de Performance Audiovisual) e EdiPAs (Edições de Performance Audiovisual; BORÉM, 2016; BORÉM; TAGLIANETTI, 2014) que ilustram as análises.

\section{2 - Considerações sobre o campo teórico referencial}

Como dissemos, nossa análise se fundamentou em "procedimentos interdisciplinares", para dar conta da compreensão da interatividade de distintos processos criativos em ação numa performance musical e cênica. Procedimentos analíticos sistematizados das artes cênicas e dramáticas foram especialmente úteis à compreensão da espacialização e da mobilização da intérprete. A ideia de uma cinesfera do músico (BORÉM, 2017; BORÉM; NOGUEIRA, 2017, adaptado de LABAN, 1978; RENGEL, 2001), ou seja, o espaço de realização musical do performer, teve como base o conceito de ocupação do espaço cênico do ator/atriz no palco. A descrição de movimentos corporais maiores (cabeça, tronco, braços e pernas) considerou os pontos de

\footnotetext{
${ }^{4}$ Por exemplo, “... em [2:07]" indica o início de um evento a cerca de 2 minutos e 7 segundos do início do vídeo.

${ }^{5}$ Em Cantos, observamos a versatilidade virtuosa na incorporação de múltiplas personagens em ação; Em Ir alten Weib, de Gilberto Mendes, nota-se a superposição de uma narrativa política à sensualidade cômica do original; e em Marthóperas, de Eduardo Guimarães Álvares, o acréscimo de cores autobiográficas à homenagem que o compositor lhe fez.

${ }^{6}$ Agradecemos ao Professor Wlad Mattos da UNESP a cópia das partituras do acervo pessoal de Martha Herr.
} 
vista da dança (LABAN, 1978), da cinesiologia/biomecânica (HAMILL; KNUTZEN, 2008) e do comportamento motor (MAGILL, 2000; SCHMIDT; WRISBERG, 2001; SCHMIDT, 1993). Conceitos como "cinemática" e "dinâmica" na dança (HAGA, 2008) e "sincronizações" na dança e cinema (HAGA, 2008 e CHION, 1994, adaptados à música por BORÉM, 2016) permitiram analisar significados explícitos e subliminares dos movimentos corporais da intérprete, observar estratégias de construção cênica da performance (BORÉM; TAGLIANETTI, 2016) e níveis de espontaneidade (BORÉM, 2016).

Por outro lado, alguns estudos dos campos da psicologia social e da psicologia do desenvolvimento (relacionados aos processos de subjetivação da experiência afetiva nas relações interpessoais) subsidiaram o entendimento do jogo de afetos sugeridos nos distintos motivos que compõem a peça (configurados em alturas, contornos melódicos, ritmos, intensidades e timbres) e sua interpretação através de recursos de emissão vocal e expressão facial em rápidas transformações.

Para subsidiar a percepção qualitativa dos afetos, recorremos ao conceito de "afetos de vitalidade" (vitality affects) ${ }^{7}$ de Daniel Stern (STERN, 1985; BEEBE et al., 2003) e, especialmente, ao Modelo Circumplexo dos Afetos de James A. Russell ${ }^{8}$. Estudos de Paul Ekman sobre o reconhecimento das emoções no rosto do ser humano (EKMAN, 2016, 1992, 1970, 1972 e 1965; EKMAN; SORENSON; FRIESEN, 1969; EKMAN; FRIESEN, 1969), especialmente ao seu método para a classificação de emoções em expressões faciais (EKMAN; FRIESEN, 2003) foram importantes na compreensão das

\footnotetext{
${ }^{7}$ Cunhada por Stern, a expressão "afetos de vitalidade" se refere à dinâmica temporal de mudança nos sentimentos, afetos, pensamentos, percepções ou sensações, constituindo "um ritmo contínuo de acelerações e desacelerações perfeitamente ligadas, que aumentam e diminuem de intensidade, que se iniciam e param [...]" (STERN, 1985, p. 57), a cada fração de segundo. Com esta denominação "experimental", Stern distingue os "afetos de vitalidade" (formas temporais de sentimento) das tradicionais emoções ("medo", "surpresa", "raiva", "nojo", "tristeza" e "alegria"), ainda que ocorram tanto na presença quanto na ausência destes. Um aspecto típico dos afetos de vitalidade é o "contorno de ativação emocional" (contour of emotional activation): espécie de índice geral de nível de excitação-ativação, através do qual experiências sensoriais diversas com contornos de ativação similares podem ser observadas como correspondentes, e, dessa forma, terem um critério de organização.

${ }^{8}$ James Russell é professor do Departamento de Psicologia de Boston College. Como pesquisador, seus interesses centram-se na natureza da emoção e no afeto nuclear (core affect). Uma consideração importante de Russell (que devemos levar em conta quando se estuda a psicologia da emoção em idiomas estrangeiros) é a de que "conceitos de emoção em inglês parecem, mas não são idênticos aos conceitos de emoção em outros idiomas" (RUSSELL, 2019, p. 3).
} 
várias nuances emotivas da interpretação (com recursos de emissão vocal e expressão facial).

Após os trabalhos pioneiros de Kate Hevner sobre afetos e música na década de 1930 e o circumplexo de termos afetivos de Charles Osgood de 1957 (EEROLA, 2018), Russell (1980) propôs um plano cartesiano com 28 descritores de afetos sobre o eixo horizontal X ("valência", da mais negativa à mais positiva) e o eixo vertical Y ("atividade", da mais baixa à mais alta), que serviu de referência para a pesquisa na interface entre música e psicologia no Brasil (MORAES, 2017; GERLING; SANTOS, 2015; RAMOS; BUENO, 2012; GERLING; SANTOS; DOMENICI, 2008; GERLING; DOMENICI; SANTOS, 2008) e que, com acréscimos (número de recorrências, trajetos entre afetos, utilização de cores e impacto na forma musical), foi aplicado à construção da performance musical cênica de modinhas imperiais (BORÉM; TAGLIANETTI, 2016). Russell refinou seu modelo renomeando o eixo $X$ como Prazer/Desprazer e reduziu os 28 afetos iniciais para 8 afetos nucleares (core affects; RUSSELL; BARRETT, 1999), traduzidos ao português em CRISPIM et al. (2017, p. 147), tal como se encontra na Figura 1.

Figura 1 - Circumplexo dos Afetos de Russell.

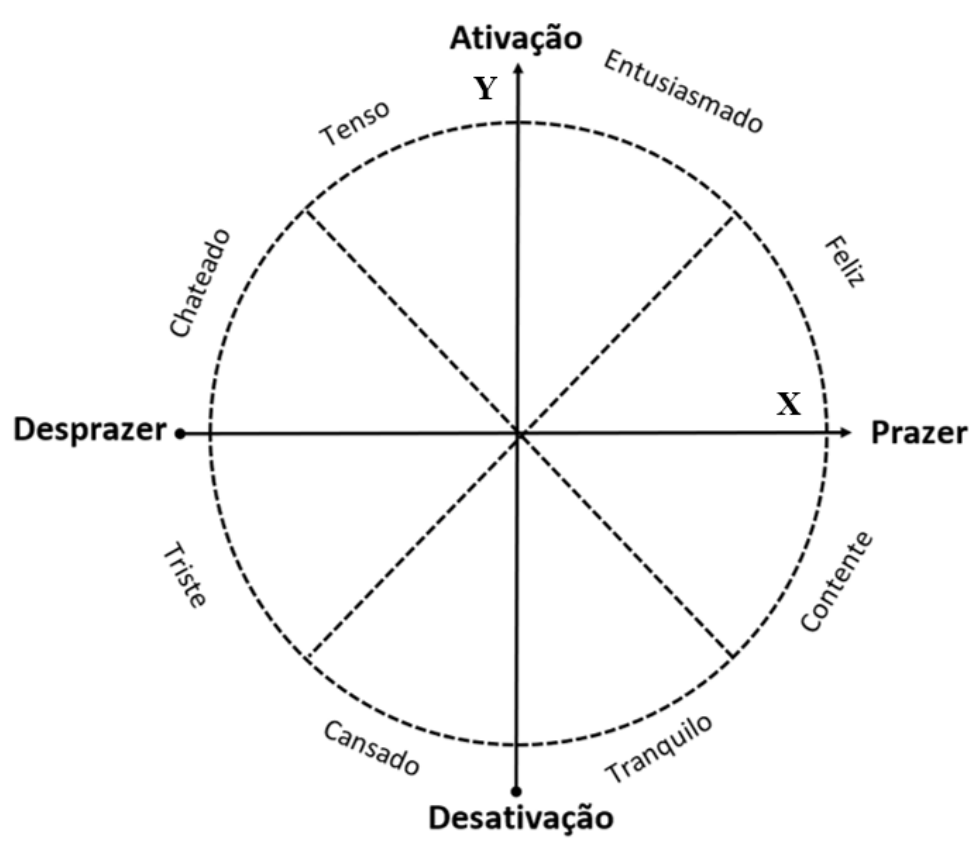

Fonte: produção dos autores, a partir da tradução em CRISPIM et al., 2017. 
O Circumplexo de Russel de 8 afetos nucleares, tal como traduzido em Crispim et al. (Figura 1), foi referencial para a construção dos Modelos Circumplexos dos Afetos que ilustram nosso entendimento da qualidade afetiva dos motivos da peça (Seção 3.3, Figura 5) e das correspondentes personagens interpretadas por Martha Herr (Seção 4, Figura 6).

\section{3 - Cantos de Tim Rescala}

Escrita em 1994, Cantos, para atriz-cantora (ou, mais apropriadamente, cantoraatriz, já que a obra é baseada em enormes demandas musicais), foi estreada no mesmo ano pela soprano Carol McDavit no Centro Cultural Banco do Brasil (CCBB) do Rio de Janeiro, no espetáculo A Música da Fala. Nas palavras do próprio compositor, a intérprete precisa enfrentar “[...] variados tipos de emissão vocal através de um discurso vertiginoso [em que] cada tipo de emissão vocal deve vir acompanhado de uma movimentação ou postura cênica específica [...]" (Rescala, apud GUSE, 2006, p. 4). Isso talvez explique o fato de que muito poucas performances desta obra emblemática foram documentadas. Além de requerer grande agilidade nas muitas, súbitas e incessantes mudanças de conformação do aparelho fonador, há o desafio de uma encenação fragmentária durante toda a obra, que exige, ao mesmo tempo, unidade na realização da macro forma para resultar em "[...] um discurso no qual a atriz/cantora "encarna” várias personagens de uma maneira rápida, um tanto esquizofrênica, sugerindo uma estética surrealista" (GUSE, 2006, p. 4). Esse "surrealismo" decorre da total aleatoriedade percebida na sequência dos múltiplos recortes motívicos que integram a peça, projetando uma estrutura aparentemente caótica.

Apesar da contínua fragmentação e total falta de causalidade (qualidade tradicionalmente tida como pré-requisito ao discurso narrativo ${ }^{9}$ ), a peça insinua trama. Requerendo a percepção de personagens e ações na música, a sugestão de uma trama depende neste caso, em grande parte, de uma interpretação criativa. Cabe à intérprete a

\footnotetext{
${ }^{9}$ Referindo-se às várias e confusas definições sobre o termo "narrativo/a" e concordando com a definição de Karol Berger em Narrative and Lyric (1993), Małgorzata Pawłowska explica: "Narrative and lyric are, according to Berger, types of form. [...] In narrative there is a sequence of parts which succeed one another in a determined order, governed by relationships of causation and resulting from necessity or probability." [De acordo com Berger, o narrativo e o lírico são tipos de forma. [...] Na narrativa há uma sequência de partes que se sucedem numa ordem determinada, governada por relações de causalidade e resultando de necessidade ou probabilidade] (PAWŁOWSKA, s. d., p. 6).
} 
finalização das personagens de Rescala, as quais, na partitura, não recebem descritores, mas são sugeridas pelo contexto musical (estereótipos culturais com os quais o compositor elabora os diferentes motivos da peça). Como narrativa, a peça exige uma performance interdisciplinar, que envolva aspectos técnicos da música e do teatro. Portanto, consideramos Cantos como descendente temporã do "novo teatro musical" 10.

\section{1 - A configuração motívica}

Cantos pode ser descrita como uma justaposição rapsódica de 10 motivos $^{11}$ contrastantes, que podem ser agrupados segundo duas grandes categorias: motivos semânticos (que carregam texto) e assemânticos (efeitos vocais e silêncio). Os motivos da categoria semântica abarcam tipos diversos que revelam um estilo composicional eclético, incluindo desde escalas tonais e modais até a estética pós-1950; desde ornamentos consolidados no barroco até o clímax dos agudos intensos e sustentados das óperas românticas italianas.

A Figura 2 mostra os motivos tipificados a partir de similaridades (o uso das cores na nomenclatura dos motivos e respectivas personagens de Cantos será explicado adiante, na seção 3.3). Configurando o Tipo I, os motivos 1, 2 e 3 (assemânticos), assim como 4 e 5 (semânticos), não contêm alturas definidas e estão na faixa de intensidades mais baixas; incluem o silêncio, os efeitos da respiração (inspiração e expiração), o murmúrio de uma reza quase incompreensível ${ }^{12}$ e um texto italiano declamado em $p p$.

\footnotetext{
${ }^{10}$ Referimo-nos ao gênero interartes que caracteriza grande parte da produção artística pós-guerras, na Europa e na América do Norte (especialmente nos anos 1960, até meados dos anos 1970). Valorizando a presença física do intérprete, o "novo teatro musical" concebeu a realização sonora com um significado dramático. Em obras de pequena escala, enfatizou-se o espetáculo e o efeito dramático em detrimento dos valores puramente musicais. Ligeti, Berio, Heenze, Schnebel, Maxwell Davies e, especialmente, Kagel sobressaíram neste gênero, onde o conteúdo musical era minimizado. A estética do caos anarquista e a ideologia de desconstrução e subversão do cânone, que caracterizam o gênero em Kagel, também identificam a estética de Cantos.

${ }^{11}$ Por "motivo" entende-se aqui a unidade musical em que um efeito vocal (motivo assemântico) ou um fragmento de texto correspondente a um perfil de alturas, estrutura rítmica, registro e nível de intensidade (motivo semântico), pela recorrência e redundância musical, adquire valor representativo, seja de "personagem" (os motivos semânticos) ou de "voz narrativa" (os motivos assemânticos, configurando uma voz senza voce, expressa em ruído ou silêncio com carga expressiva "afetiva", construindo e desconstruindo expectativa e tensão influentes na percepção das personagens). $\mathrm{Na}$ obra, os motivos se fragmentam ou se expandem sem perder sua identidade fundamental.

12 A partitura não especifica um texto para esse motivo, cuja identificação como "reza" se encontra na bula ("Simbologia"). Desta forma, infere-se que o texto da reza seja aleatório, e que a anotação da "Ave Maria" na partitura de Martha Herr, de próprio punho, seja a sua escolha.
} 
Figura 2 - Os 10 motivos assemânticos e semânticos de Cantos agrupados em 4 tipos: I) motivos sem altura definida, II) motivos com contorno melódico de 4 a justa descendente, III) motivos com bordadura entre as classes de notas Lá e Sib, e IV) motivo com foco no Registro 5, em dinâmica $f$.

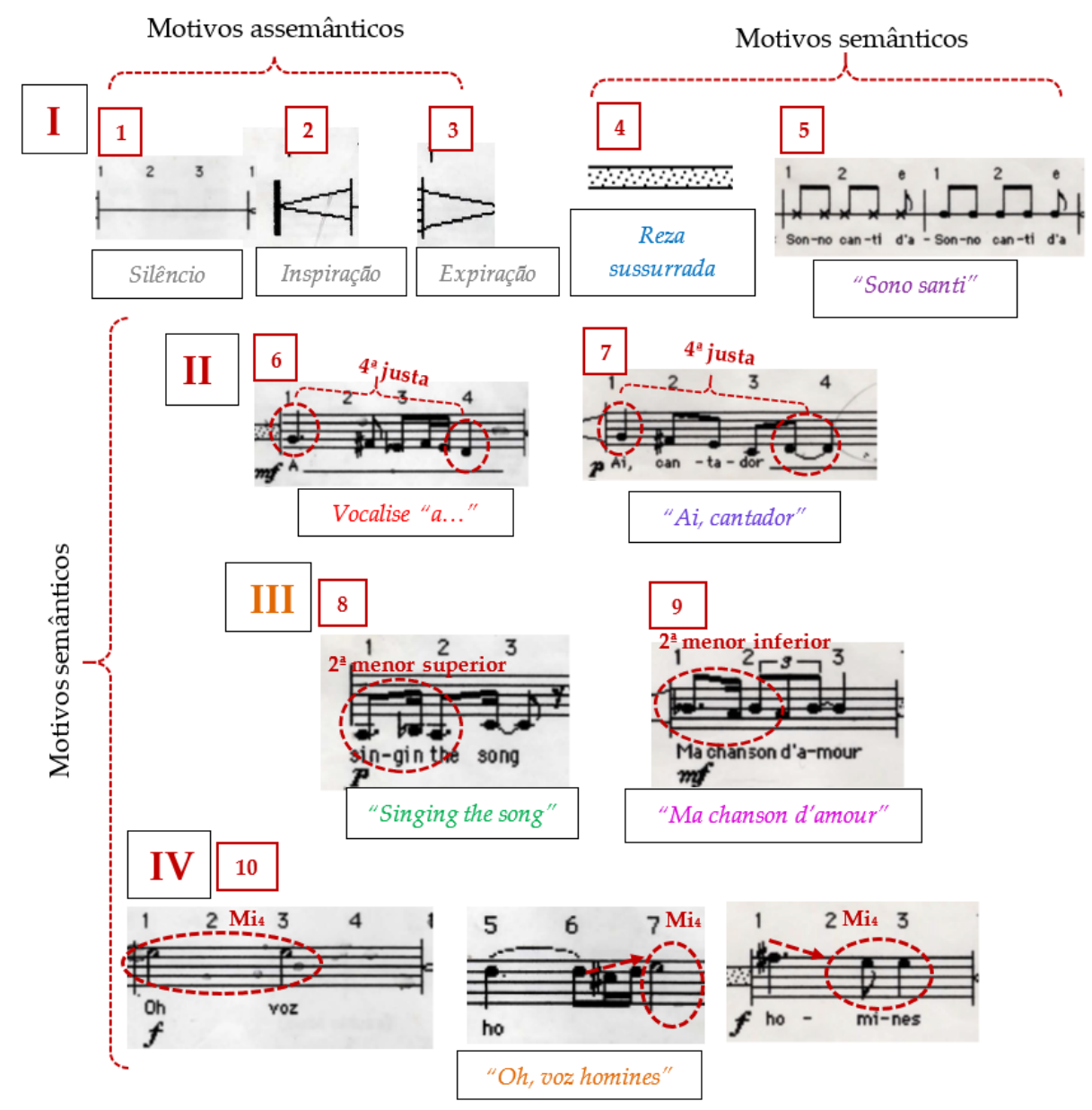

Fonte: Reprodução autorizada pelo compositor.

O Tipo II abrange os motivos 6 e 7, derivados de escalas modais que remetem ao modalismo árabe e ao nordestino, delineando, portanto, uma interculturalidade conspícua; a direção descendente, a delimitação no intervalo de $4^{\mathrm{a}}$ justa e a máxima comunalidade do conteúdo de alturas $\left(\mathrm{Sol}_{4}-\mathrm{Fá}_{4}-\mathrm{Ré}_{4}\right)^{13}$ os aproxima musicalmente.

Constituindo o Tipo III, os motivos 8 e 9, projetando a palavra canção em inglês e francês, se identificam também pela bordadura de $2^{\mathrm{a}}$ menor (superior ou inferior) com as mesmas classes de notas (Lá e Sib) e mesma célula rítmica.

No Tipo IV encontra-se o motivo 10, na região mais aguda da obra (registro 5), também contido no âmbito de uma $4^{\mathrm{a}}$ justa; transitando entre o português ("voz") e o

\footnotetext{
${ }^{13}$ Adotamos a convenção que designa o Dó central do piano como Dó4.
} 
latim (homines, plural de homo). Este motivo pode conduzir, pela homofonia do texto, a uma associação com o Canto da Verônica: o responsório $O$ vos omnes [Ó, vos todos...], tradicionalmente cantado durante a Quaresma e a Semana Santa ${ }^{14}$.

O já mencionado ecletismo estilístico é traduzido numa notação musical igualmente eclética, que utiliza grafismos para efeitos concernentes à estética pós-1950 (motivos do Grupo I) e notação tradicional na pauta (motivos dos Grupos II, III e IV). Os números acima dos sistemas indicam durações (em pulsos). Considerando o tempo sugerido (semínima $=80)$, os 347 pulsos da partitura correspondem a uma duração aproximada de 4 minutos e 20 segundos.

O desenvolvimento motívico (com ênfase especial em recursos como redundância, distribuição e substituição) sinaliza para uma estrutura formal com três partes principais e três seções subsidiárias Introdução, Seção A, Seção B, Interlúdio, Seção C e Coda. A interação de motivos assemânticos e semânticos desempenha um papel central na definição da forma.

\section{2 - A Estrutura motívica e sua potencialidade narrativa}

A observação dos motivos de Cantos do ponto de vista de sua potencialidade narrativa nos leva a recordar como Heinrich Schenker considerou o motivo em seu Tratado de Harmonia [Harmonielehre] (1906):

O motivo, e apenas o motivo, cria a possibilidade de associações de ideias [...]. Primordial e intrinsecamente, o motivo é uma associação de ideias. Ele substitui a poderosa e eterna associação de ideias a partir de padrões da natureza, na qual as outras artes são pujantes (SCHENKER, 1954, p. 4). ${ }^{15}$

Considerando a repetição como princípio inerente ao motivo, Schenker o define, simplesmente, como "uma série de sons recorrente". E reconhece que não somente a melodia, mas também outros elementos da música (como o ritmo, a harmonia etc.) podem

\footnotetext{
${ }^{14}$ A associação ao texto do Livro das Lamentações de Jeremias (Capítulo 1, Versículo 12) - O vos omnes / Qui transitis per viam, /Attendite, et videte / Si est dolor similis sicut dolor meus [Ó, vós todos que passais pelo caminho, vinde e vede se existe dor tão grande quanto a minha] - concede aos fragmentos "Oh, voz" (português) e "Homines" (latim) uma indiscutível unidade motívica. Quanto ao uso do substantivo em português "voz" substituindo o pronome latino "vos", isto pode referir-se à instrumentação da obra (a voz), da mesma forma que a mistura gramatical, aparentemente "irresponsável" ou "inculta", pode referir-se ao estado mental anormal que a obra sugere.

15 "The motif, and the motif alone, creates the possibility of associating ideas, [...]. The motif is a primordial and intrinsic association of ideas. The motif thus substitutes for the ageless and powerful associations of ideas from patters in nature, on which the other arts are thriving" (SCHENKER, 1954 [1906], p. 4).
} 
ser capazes de criar associações de ideias e, portanto, ter valor motívico. A repetição variada, a imitação, diz ele, "não cancela o efeito mágico da associação" (SCHENKER, 1954, p. 7). Comparando a evolução do motivo na obra musical ao destino da personagem no drama - onde diversas situações revelam diferentes facetas da personalidade e definem o caráter integral do indivíduo -, Schenker admite que as variantes às quais um motivo musical é submetido (melódicas, harmônicas, rítmicas) são análogas às situações que testam o caráter do herói (o motivo, na música). Ele conclui seu pensamento desta forma

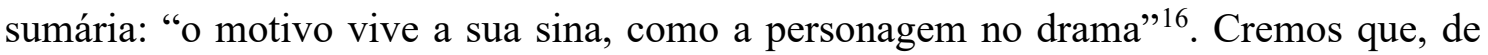
certo modo - e, talvez, pioneiramente -, Schenker reconheceu e teorizou (de uma forma especificamente baseada em narrativas biológicas e teleológicas) sobre o potencial narrativo (ainda que não tenha usado este termo) do motivo e da música:

\footnotetext{
Devemos nos acostumar a ver as notas como criaturas. Devemos aprender a presumir nelas ímpetos biológicos, já que caracterizam [grifo nosso] seres vivos. Defrontamo-nos, portanto, com a seguinte equação:

Na natureza: ímpeto procriativo > repetição > espécie individual;

Na música, analogamente: ímpeto procriativo $>$ repetição $>$ motivo individual ${ }^{17}$ (SCHENKER, 1954, p. 6-7).
}

Conhecendo as considerações de Schenker, elas vêm imediatamente à mente quando, ouvindo a performance de Cantos com Martha Herr, percebemos a potencialidade referencial, associativa, dos motivos, únicos elementos dos quais a peça se compõe ${ }^{18}$. É justamente dessa qualidade referencial, composicionalmente elaborada por Rescala e interpretativamente evidenciada por nossa cantora-atriz, que a narratividade da peça depende.

Observemos, então, a funcionalidade narrativa na concepção dos diferentes motivos, considerando seus atributos musicais aliados à sua distribuição na peça. Primeiro, trataremos dos motivos assemânticos: o Silêncio, a Inspiração e a Expiração (apresentados em suas respectivas notações na Figura 2 acima, como motivos 1, 2 e 3).

\footnotetext{
16 "The motif lives through its fate, like a personage in a drama." (SCHENKER, 1954, p. 13).

17 "We should get accustomed to seeing tones as creatures. We should learn to assume in them biological urges as they characterize living beings. We are faced, then, with the following equation: In nature: procreative urge > repetition > individual kind; in music, analogously: procreative urge > repetition > individual motif."

${ }^{18}$ A concepção musical de Cantos pode ser descrita como uma colagem de motivos, sem que haja elementos episódicos, não recursivos, sejam de natureza introdutiva, transitiva ou conclusiva.
} 


\subsection{1 - A funcionalidade narrativa dos motivos assemânticos}

A alternância entre silêncios e inspirações constitui o total da Introdução e do Interlúdio (entre as Seçães $\boldsymbol{B}$ e $\boldsymbol{C}$ ) e, quase inteiramente, a Coda. A Introdução e o Interlúdio são seções idênticas, onde a recorrência de silêncios progressivamente mais curtos entre inspirações sugerem um accellerando (Figura 3). Já a Coda, é quase uma retrogradação da Introdução (exceto pelo pequeno trecho cantado em boca chiusa). Ali, a recorrência gradativamente mais longa do silêncio entre as inspirações sugere um rallentando para fechar a obra (Fig. 3).

Figura 3 - Sugestão de accellerando na Introdução e rallentando na Coda de Cantos, de Tim Rescala.
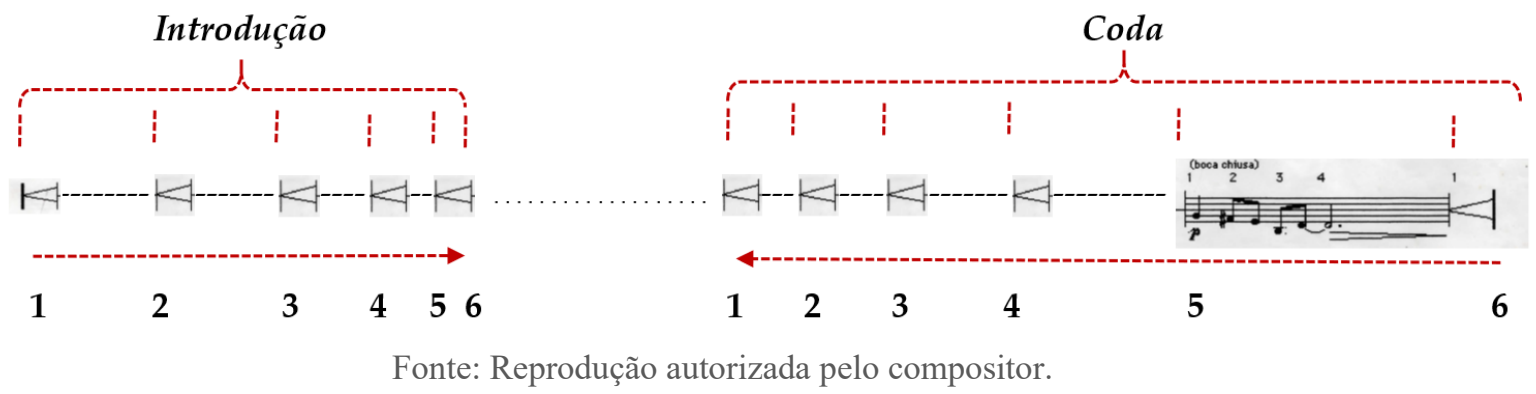

O motivo Inspiração (inalação do ar pela boca) é o mais recorrente na peça. Além de constituir o elemento exclusivo da Introdução e do Interlúdio (e quase da Coda),

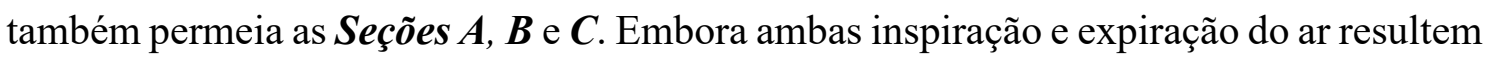
de contrações musculares, as ações dos músculos intercostais externos inflando os pulmões é mais notável visualmente do que as ações dos músculos intercostais internos para esvaziar os pulmões. Por isso, o motivo Inspiração é mais propício para sugerir "apreensão" e "surpresa" e, devido à sua grande recorrência, atua na peça como força motriz de expectativa e construção de clímaces. Já o motivo Expiração sugere distensão, relaxamento, alívio. Nota-se que a inspiração geralmente introduz um motivo semântico, enquanto a expiração o conclui, ou segue imediatamente uma inspiração, numa espécie de compósito motívico "tensão-relaxamento".

A distribuição desses motivos assemânticos, introduzindo a peça, dividindo-a ${ }^{19}$, finalizando-a, e ainda intercalando-se entre motivos semânticos (introduzindo-os ou

\footnotetext{
${ }^{19}$ É notável o fato de a Seção Áurea da peça (entre as pulsações 214 e 215) localizar-se quase exatamente no ponto entre o final do Interlúdio e o início da Seção $\boldsymbol{C}$ (entre as pulsações 216 e 217).
} 
concluindo-os), confere-lhes, em nossa percepção, a função de expressar uma "voz narrativa" sui generis, que se manifesta através de efeitos vocais dotados de grande potencial afetivo, isto é, de um semiotismo imanente. Poderíamos considerar essa "voz" narrativa como expressão do "inconsciente estruturado como linguagem" (lembrando aqui o axioma lacaniano)? Se admitimos a plausibilidade, estamos atribuindo competência linguística ao reduto dos afetos, substância "extracorpórea" da linguagem. Diríamos que os motivos assemânticos representam o inconsciente em comando, dirigindo a emergência e submergência de retalhos da consciência (os diversos motivos semânticos), substratos da memória em caótico fluxo, na ânsia por um nexo impossível.

\subsection{2 - A funcionalidade narrativa dos motivos semânticos}

Um notável "atropelo motívico" ocorre na continuidade da composição, como se fossem vários planos, tomadas (takes) e cortes de uma filmagem compondo um resultado que parece pretender emular um making of (cenas de bastidores) de obra cênica de maior envergadura, da qual os recortes selecionados foram propositalmente embaralhados, como um "quebra-cabeças" para oferecer-se ao ouvinte. Esse resultado também pode apresentar-se como um panorama imaginário de múltiplas personagens femininas, representantes de diferentes culturas, expressando-se em característicos gestos musicais (sejam cantados ou falados), atuando ao mesmo tempo em diferentes partes do mundo.

Apesar da inescapável linearização cronológica da voz solista, a peça consegue, em seu método de fragmentação e entrelaçamento motívico, construir uma sensação de simultaneidade, de uma verdadeira polifonia de vozes e gêneros do canto, marcada por interculturalidade e inter-historicidade. Não se deve desprezar também a já citada sugestão de que a peça reflita um surto de esquizofrenia (GUSE, 2006), considerando-se a falta de conexão lógica na sequência motívica; como se aos motivos (diferentes vozes ouvidas na mente esquizofrênica) faltassem bordas que impedissem sua diluição e interpenetração. Antecipamos aqui, portanto, o que consideramos como a essência narrativa de Cantos.

A caracterização musical dos motivos semânticos e sua distribuição na temporalidade da peça (Seções $\boldsymbol{A}, \boldsymbol{B}$ e $\boldsymbol{C}$ ) importam na percepção de sua potencialidade narrativa. A Seção $\boldsymbol{A}$ inicia com o diálogo entre os motivos Reza sussurrada e "Oh, voz 
homines", literalmente opostos em suas configurações musicais: uma intimista recitação murmurada, quase inexplícita em seu ritmo veloz, e um imponente recitativo de notas prolongadas, repetidas, em intensidade $f$, no registro agudo. Considerando a associação do recitativo cantado ao "Canto da Verônica", pode-se dizer que sua exaltação "vocativa" atenta para o drama implícito no recitativo murmurado. É inequívoco, portanto, o ambiente de religiosidade que se instaura neste diálogo. Pouco adiante insere-se o Vocalise " $a$ ", remetendo ao canto árabe pela natureza melismática e bordadura sobre o intervalo de $2^{\mathrm{a}}$ aumentada ${ }^{20}$; as características musicais desse vocalise intermediam, de certa forma, as dos dois motivos antecedentes, sendo realizado no registro médio e sempre em $m f$. A partir desse "triálogo", a interculturalidade da peça começa a ser desenvolvida.

Ao adentrar a Seção $\boldsymbol{B}$, um novo "diálogo" intercultural se superpõe, em novos idiomas. Trata-se dos motivos "Singing the song" 21 e "Ma chanson d'amour", que apesar de representarem distintas tradições musicais do grande gênero canção, "tocamse" musicalmente através da bordadura, respectivamente ascendente e descendente, sobre as mesmas classes-de-notas: Lá e Sib, em relação de oitava. $\mathrm{Na}$ continuidade, o entrelaçamento motívico dá a perceber a instalação de um verdadeiro caos estrutural, compondo um colóquio onde a interatividade não sugere intercomunicabilidade.

A interrupção desse estado babélico pelo retorno da Introdução como Interlúdio pode trazer a sensação de fechamento cíclico, criando a expectativa de um possível final, que é frustrado com a entrada de um novo motivo: "Sono canti", o qual abre uma nova expectativa introduzindo a $\boldsymbol{S e c ̧ a ̃ o ~} \boldsymbol{C}$. Percebe-se, então, o início de uma segunda fase da evolução narrativa, onde o recitativo falado em italiano - breves expressões vocabulares, frases interrompidas, sussurradas e imediatamente repetidas em fala normal -, pode ser compreendido como referente aos farrapos da memória de tantos cantos lembrados ao acaso na fase antecedente; os distintos "cantos" de tristeza e de amor que se misturam, subliminarmente, na peça: "sono canti de tris[tezza]", sono canti d'a[more]", "per cantare", "tutti questi canti", "sotto voce", "triste canta", "canta piü”, "parla mai”,

\footnotetext{
${ }^{20}$ Como $2^{\mathrm{a}}$ aumentada, interpretamos o intervalo característico das "escalas" árabes no sistema intervalar ocidental.

${ }^{21}$ Revisão ortográfica solicitada pelo compositor (na partitura, "Singin").
} 
"canta mai" "22. Caracteriza essa segunda fase a ausência da Reza sussurrada, motivo de

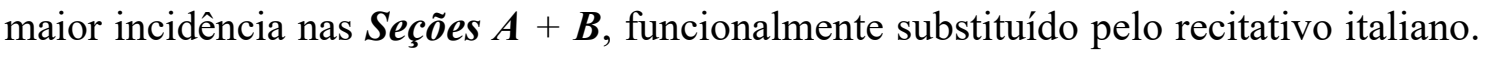
Uma nova carga semântica e cultural conduz o motivo "Sono canti" a uma interpretação funcional essencialmente narrativa. Um novo motivo, "Ai, cantador", junta-se à produção do caos esquizofrênico que se estende até o final da obra. A sugestão do modalismo brasileiro nordestino (mixolídio em Ré? Lídio em Dó?), encerra a interculturalidade da peça. Sugestivamente, a última expressão verbalizada na peça é “canta, mai”, após a qual tem início a Coda.

A Coda é uma espécie de retrógrado da introdução em tensão decrescente. O fragmento melódico conclusivo em boca chiusa remete, inequivocamente, ao motivo brasileiro "Ai, cantador", como memória se esvanecendo na nota final prolongada em dinâmica decrescente (veja a Figura 3, acima). A finalização em $\mathrm{Si}_{3}-\mathrm{Ré}_{4}$ (substituindo Dó4-Ré4 no motivo cantado com palavras) transforma a percepção de uma elocução modal numa elocução de característica mais tonal - e mais "conclusiva" - (pela configuração da tríade de Sol Maior). O "ponto final" da peça é o motivo da Inspiração, cuja implícita carga de tensão sugere a permanência do transtorno psíquico, provável tema de $\operatorname{Cantos}^{23}$.

A EdiPA da Figura 4 sintetiza a forma de Cantos, organizada a partir de seus 10 motivos (dispostos no eixo Y) e suas 180 ocorrências (ao longo no eixo X). Os motivos estão hierarquizados de acordo com suas dinâmicas ( $p p$ a ff) e registros vocais (do grave ao agudo). Se percebermos a fermata entre as $\boldsymbol{S e c ̧ \tilde { e } e s ~} \boldsymbol{A}$ e $\boldsymbol{B}$ como uma interrupção mínima que não afeta o fluxo narrativo, então podemos também perceber a forma de Cantos não como ternária, mas como binária.

\footnotetext{
${ }^{22}$ Em diálogo a respeito da peça, o compositor solicitou a revisão ortográfica dos seguintes termos: "Sonno" (deve ser "Sono"), "cantate" (deve ser "cantare"), e "piú" (deve ser "piü"). Na articulação fragmentada, pode se inferir a palavra "amore" assim como se infere "tristezza" (prováveis referências a "Ma chanson d'amour" e "Ai, cantador").

${ }^{23}$ Na performance, Martha Herr substitui a inspiração por um grito de pavor (diante da visão do pano negro do qual se desvencilhara em sua saída de cena). Muito apropriada para sugerir outro final para a peça, a substituição da última recorrência do motivo Inspiração por um Grito de pavor (comentada mais adequadamente na seção seguinte) demonstra não só a sagacidade da intérprete quanto sua desenvoltura e independência em cena.
} 


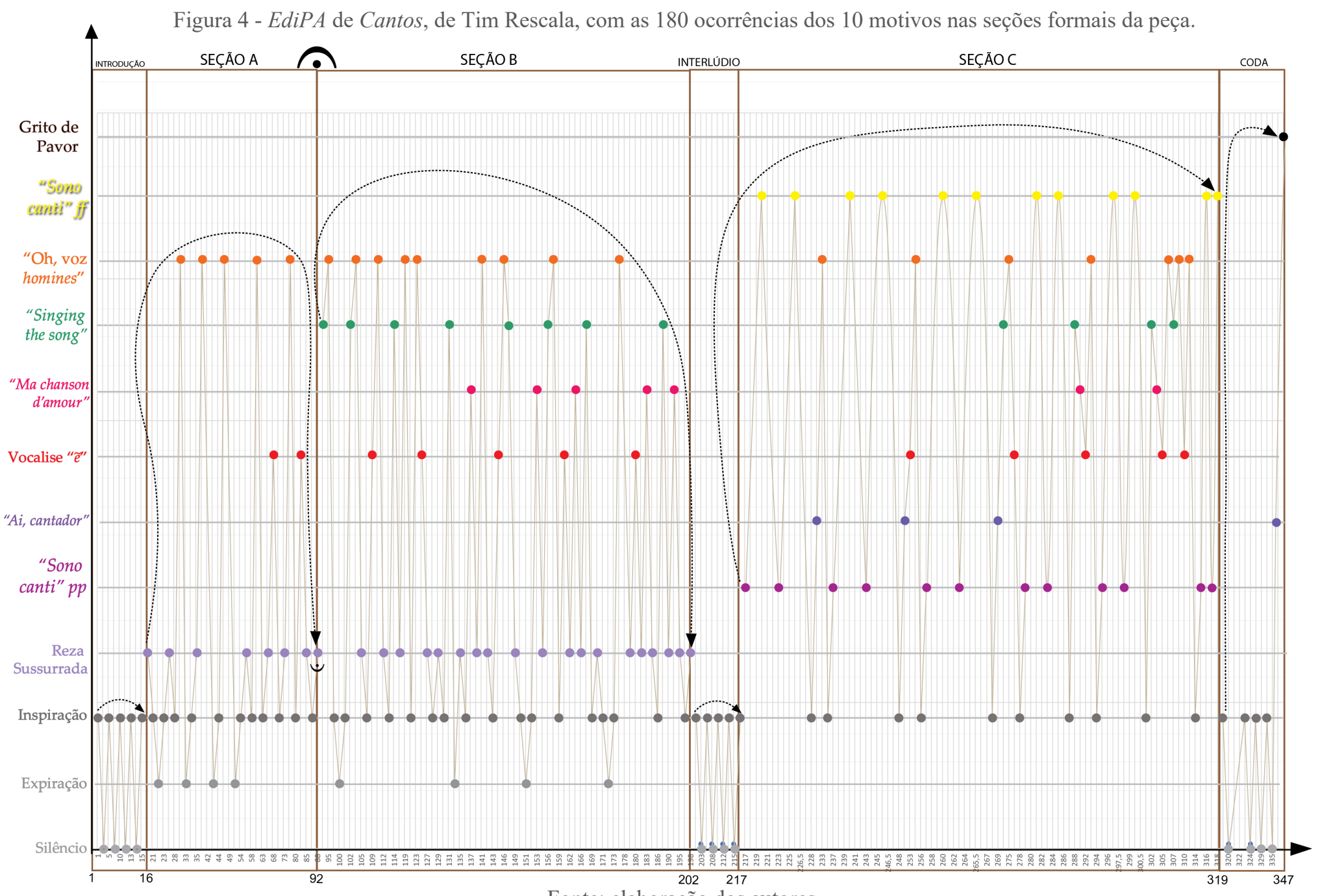

Fonte: elaboração dos autores. 


\section{3 - Aplicação do Circumplexo dos Afetos à análise dos motivos em Cantos}

Aplicaremos agora o Circumplexo dos Afetos de Russell aos afetos que podem ser inferidos nos motivos de Cantos, no sentido de dimensioná-los nos níveis de prazer/desprazer (eixo horizontal X) e ativação/desativação (eixo vertical Y; que também associamos a energia/letargia). O objetivo é a compreensão da mobilidade dos afetos qualificados no plano formal da peça, mobilidade esta que poderá servir ao entendimento de uma possível estrutura narrativa. Observemos os 6 planos cartesianos da Figura 5, onde registramos os motivos semânticos em cores cujas gradações variam do azul (menor prazer) ao vermelho (maior prazer) no Eixo $\mathrm{X}$, e do roxo (menor ativação) ao amarelo (maior ativação) no Eixo Y; e os motivos assemânticos, na relativa neutralidade do preto $^{1}$.

Na Figura 5, os modelos circumplexos "b", "c" e "e", com análises das qualidades afetivas dos motivos, revelam que as principais seções formais de Cantos (Seção A, Seção B e Seção C) são emolduradas por seções secundárias (Introdução, Interlúdio e Coda) constituídas basicamente pelo motivo Inspiração. Estas seções secundárias apresentam baixa variedade motívica, baixa intensidade sonora (sempre em pianissimo) e gradações de prazer-desprazer neutras (parte central do eixo X).

\footnotetext{
${ }^{1} \mathrm{O}$ uso das cores na nomenclatura dos motivos e respectivas personagens seguiu os princípios teóricos e pioneiros do escritor alemão J. W. von Goethe (Zur Farbenlehre, 1810), especificamente no que diz respeito ao "efeito sensorial-ético" das cores (PAWLIK, 1974, p. 117-131). Por meio da dispersão da luz, ele arranjou as cores em 6 áreas ao redor de um círculo. Nos modelos circumplexos da Figura 6, correlacionamos o círculo de cores de Goethe ao Circumplexo dos Afetos de Russell e situamos os motivos e personagens nos planos cartesianos de acordo com o contínuo entre azul e vermelho (simbolizando, respectivamente, desprazer e prazer) e o contínuo entre violeta e amarelo (simbolizando, respectivamente, a desativação e a ativação). Para os motivos assemânticos (Silêncio, Inspiração e Expiração) da voz Narradora, neutros em relação a identidade cultural (marca das personagens incorporadas no discurso narrativo), utilizamos gradações da cor preta. A hierarquização afetiva dos motivos partiu de estimativas qualitativas baseadas nos valores quantitativos de Russell (1980, p. 1174).
} 
Figura 5 - Modelos Circumplexos dos Afetos “ $a$ ”, " $b$ ”, “c”, “d”, “e”, "f” em Cantos, de Tim Rescala, com motivos distribuídos nas seções Introdução, Seção A, Seção B, Interlúdio, Seção C e Coda.
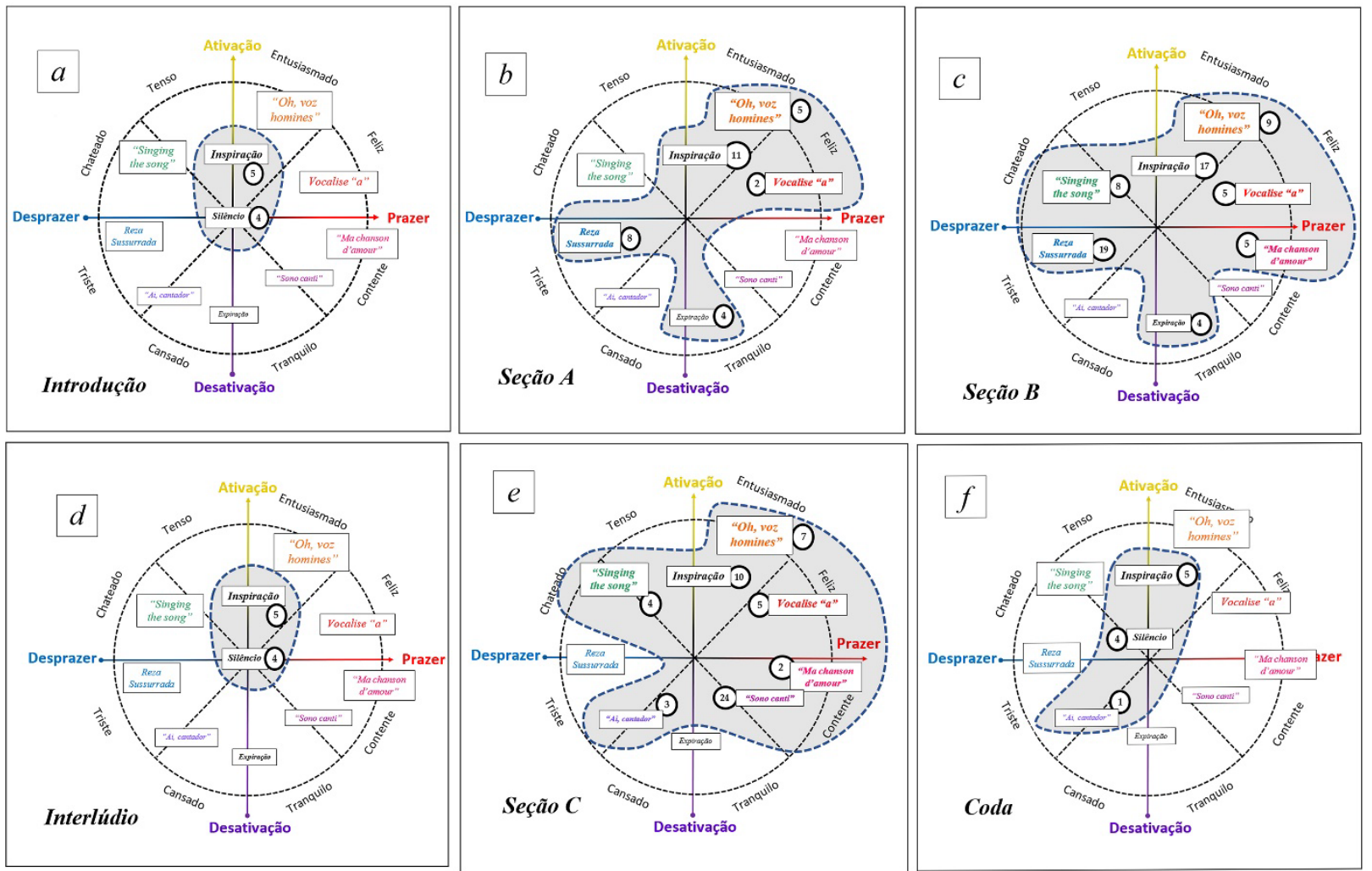

Fonte: elaboração dos autores.

Esses circumplexos também nos mostram que há uma intensificação de recorrência

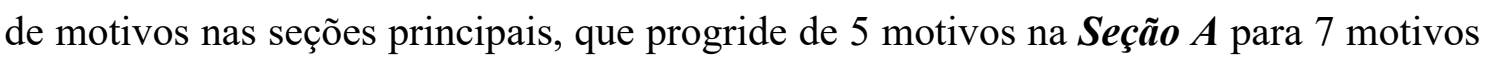

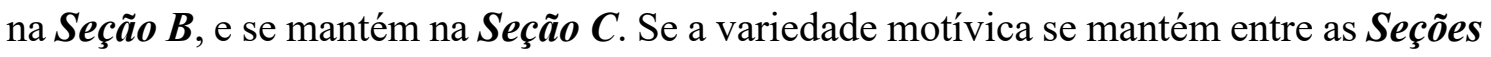

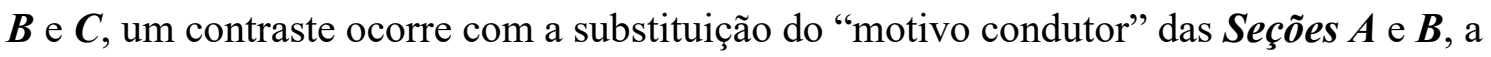
Reza sussurrada, pelo motivo "Sono canti", que conduz a Seção $\boldsymbol{C}$. Nesse ponto, a percepção de uma "transvaloração cultural" é o que fundamenta o entendimento da narrativa musical, de acordo com a teoria da narratividade musical de Byron Almén ${ }^{2}$.

\footnotetext{
${ }^{2}$ Musical narrative is the process through which the listener perceives and tracks a culturally significant transvaluation of hierarchical relationships within a temporal span." ["Narrativa musical é o processo por meio do qual o ouvinte percebe e acompanha uma transvaloração culturalmente significativa de relações hierárquicas dentro de extensão temporal"] (ALMÉN, 2003, p. 12).
} 
Assim, podemos pensar o discurso musical de Cantos como uma narrativa estruturada em duas partes intermediadas pelo Interlúdio. O recitativo sussurrado da primeira parte, que em termos de afeto é um episódio "negativo" (isento de prazer e com intensidade/energia vocal baixa), é substituído na segunda parte pelo recitativo falado, com notável ganho em dimensão de prazer e intensidade/energia vocal.

\section{4 - A emoção como fator narrativo na performance de Martha Herr}

A observação da narratividade da performance de Cantos requer o trabalho analítico a partir de dois conceitos interdependentes: personagem e emoção. Na música, a personagem é uma construção idealizada, correspondente à antropomorfização de temas ou motivos a partir da sua carga afetiva. Em Cantos, a carga semântica das diferentes expressões vocabulares em distintos idiomas associada às peculiaridades musicais de diversas origens culturais é o que sugere a antropomorfização dos motivos, concedendolhe valor representativo de personagens. $\mathrm{Na}$ construção da personagem, observamos analiticamente o comportamento expressivo e ativo do/a intérprete no uso do corpo (linguagem corporificada) e dos recursos vocais, além da mobilidade no espaço cênico. Especial valor é dado à configuração emotiva dos afetos identificáveis nos motivos dos quais as personagens emergem ${ }^{3}$; e para tanto, a teoria de Russel é significativamente útil, especialmente em suas considerações sobre a projeção da qualidade da emoção em termos de prazer/desprazer e ativação/desativação exteriorizados nas expressão faciais e gestuais da cantora-atriz.

Se, como explica o próprio compositor, Cantos está "aberta às sugestões da cantora" (RESCALA, 2018) ${ }^{4}$, vamos demonstrar agora como Martha Herr ocupa este espaço criativo, expandindo a interpretação musical stricto sensu e até mesmo reinventando certos requisitos composicionais para dar "vida" a um discurso narrativo onde ela interpreta múltiplas personagens: a Narradora (protagonista) e mais sete personagens estereotípicas que incorpora ${ }^{5}$. A estas atribuímos nomes assinalados com cores relativas às denominações de seus respectivos motivos: Diva do Bel Canto ("Oh,

\footnotetext{
${ }^{3}$ Estamos considerando "emoção" como a expressão pessoal e particularizada do "afeto". Como tal, as, emoções particularizam a interpretação, conferem-lhe identidade.

${ }^{4}$ Agradecemos a Tim Recala pela paciência e generosidade em compartilhar os bastidores de Cantos em vários e-mails trocados com o autor Fausto Borém no ano 2019.

${ }^{5}$ Adiante, na Seção 4.1, explicamos quando e como a cantora se introduz como personagem na narrativa.
} 
Voz Homines"), Diva do Jazz ("Singing the song"), Diva da Chanson ("Ma chanson d'amour"), Árabe Microtonal (Vocalise “a”), Cantadô Nordestino ("Ai, Cantador"), Diva do Recitativo pp (Sono Canti, cuja qualidade afetiva Martha redesenha mudando a dinâmica (de $p p$ para para $f f$ ) e a postura corporal, gerando a personagem Diva do Recitativo ff) e Carpideira (Reza Sussurada).

Os modelos circumplexos da Figura 6 sumarizam as principais personagens estereotípicas e intervenções de Martha Herr na macroforma definida na partitura. Ambas as Figura 6 e 7 serão discutidas em detalhe nas próximas seções. Já o MaPA apresentado na Figura 7 (com fotogramas de "a" até "o") mostra as encenações de Martha Herr, com as quais ela constrói as personagens interativas da peça.

Figura 6 - Modelos Circumplexos dos Afetos com personagens estereotípicas e intervenções de Martha Herr (Narradora) na Introdução, Seção $C$ e Coda (compare os circumplexos " $a$ ", " $e$ " e "f " com a Fig. 5 acima).
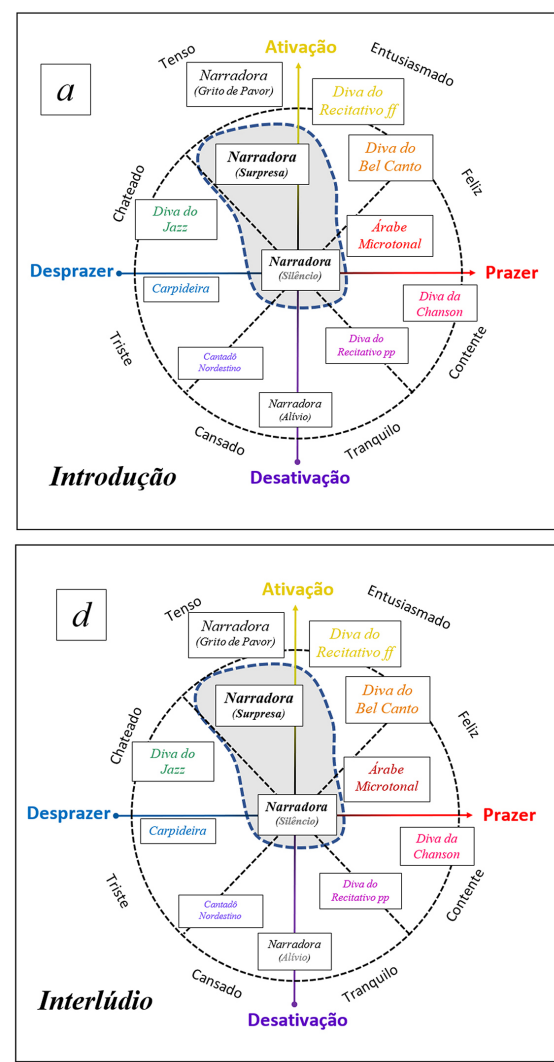
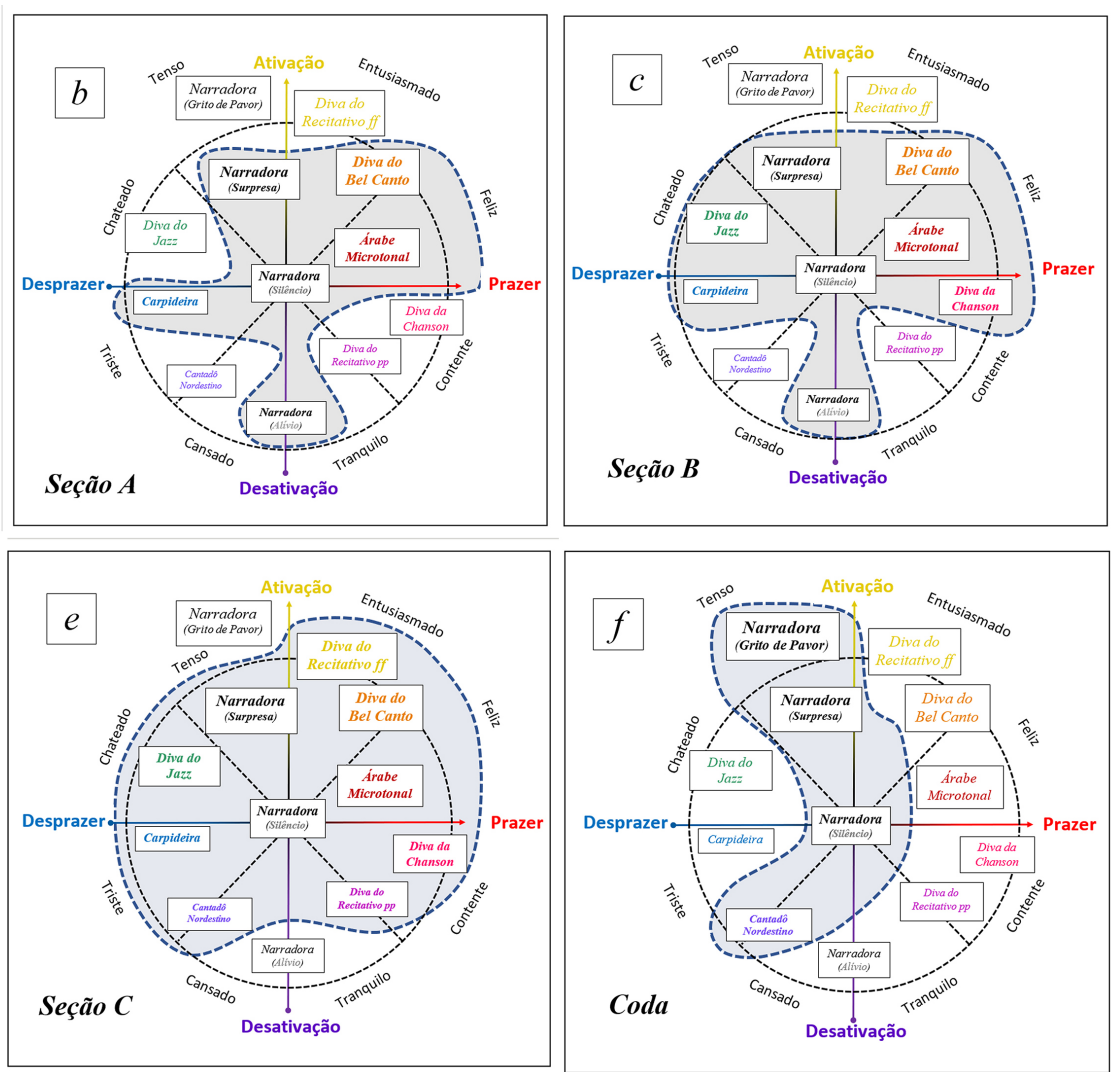

Fonte: elaboração dos autores. 
Figura 7 - MaPA da performance de Cantos por Martha Herr: uso da cinesfera (trasladação, ampliação e retração) no processo de incorporação, personalização e desincorporação de suas personagens.

Introdução (Incorporação)

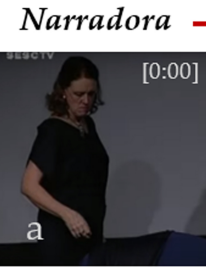

(desconfiança) (silêncio)

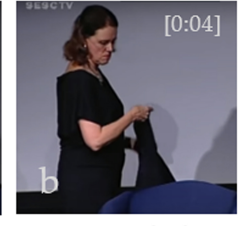

(curiosidade) (silêncio)

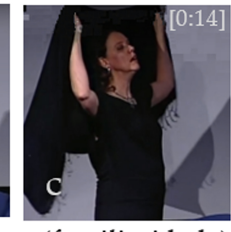

(familiaridade) (silêncio)

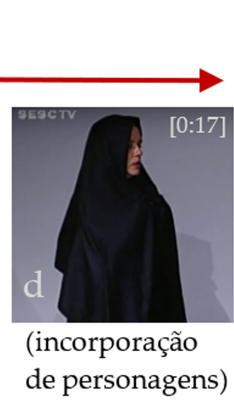

(silêncio)

Coda (Desincorporação)
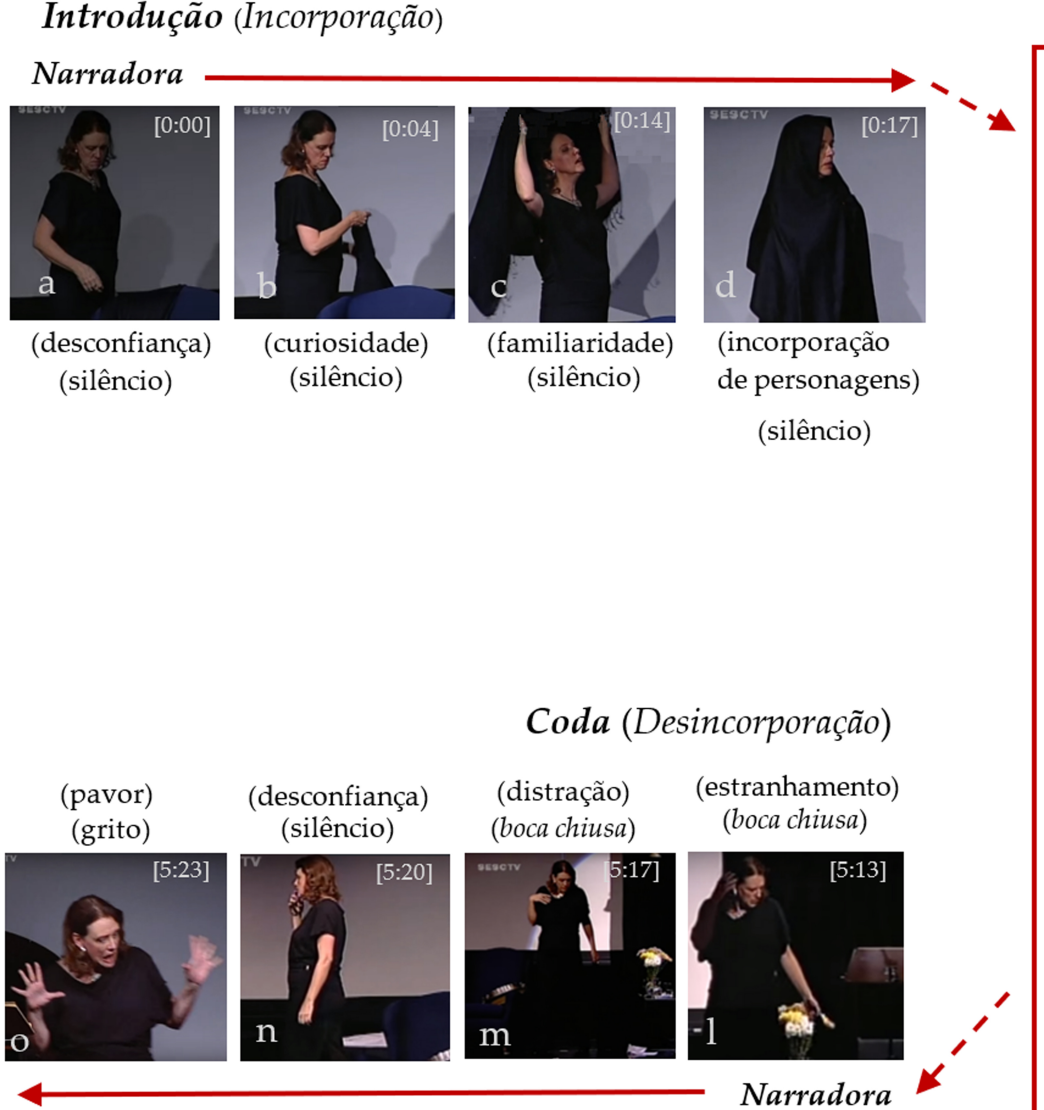

Seções $A, B$, Interlúdio, $C$

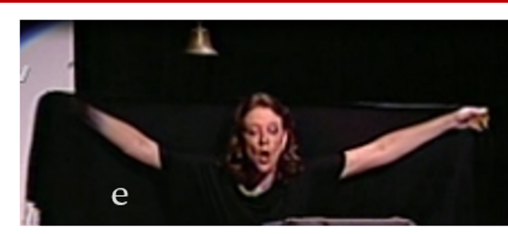

Diva do Bel Canto / Diva do Recitatioo ff
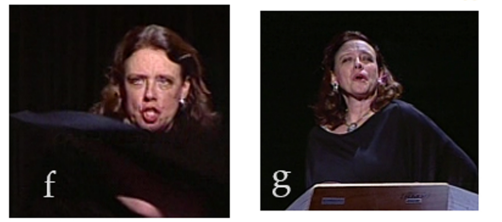

Diva do Jazz

Diva da Chanson
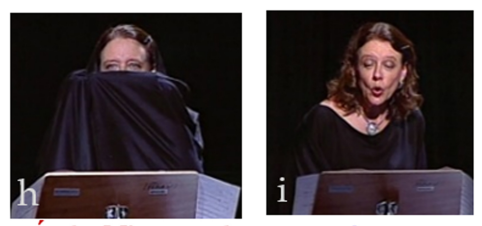

Árabe Microtonal

Cantadô Nordestino
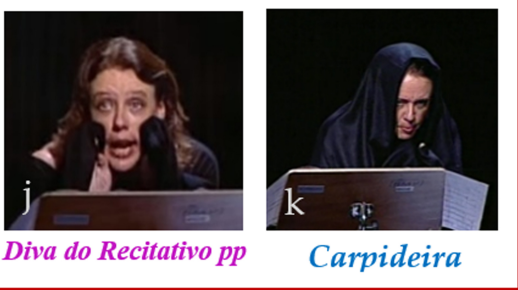

Diva do Recitativo pp

Carpideira

Fonte: adaptado de HERR; RESCALA, 2008.

\section{1 - Rituais de entrada e saída de cena}

$\mathrm{Na}$ performance de Martha Herr, o que geralmente poderia ser uma corriqueira entrada no palco se transforma em uma espécie de ritual cênico que define para a peça, antecipadamente, seu indiscutível caráter narrativo. Com uma entrada cênica silenciosa (na Figura 6, veja a parte baixa do Circumplexo "a"; e, na Figura 7, veja a sequência dos fotogramas "a", "b", “c", “d"), Martha Herr antecipa o início da peça com uma performance cênica silenciosa, que se pode definir como um ritual de incorporação da personagem Narradora. Somente a expressão facial com que adentra o palco já indica que a cantora está atuando, protagonizando uma personagem cuja construção, em andamento, depende de um objeto de cena: um tecido retangular negro o qual ela encontra 
sobre uma poltrona em seu percurso ${ }^{6}$, apanha, estende, examina, e lentamente coloca-o sobre a cabeça.

Já indumentarizada com uma espécie de "véu fúnebre", Martha imediatamente dá início à interpretação musical, realizando a Introdução enquanto caminha em direção à estante com a partitura (o locus da performance) ${ }^{7}$. A repetição dos efeitos vocais de inspiração ruidosa intercalados de silêncios cada vez mais curtos, configurando-se como uma voz narrativa muda e integralmente definida por afetos, é encenada por Martha Herr como "narrador-personagem", isto é, aquele que conta a história em $1^{a}$ pessoa e participa dos eventos que está narrando. Durante essa curta narrativa imaginária, o espectador pressupõe o afeto "angústia" (derivado das emoções "surpresa" e "medo"), que pode sugerir temor, surpresa e, mesmo, pânico. Esta cena conduz à incorporação da personagem que reza sussurrando, em cinesfera retraída ao máximo, postura encolhida e recolhida no "véu", como a Carpideira (veja fotograma na Figura 7).

Ao final da peça, um ritual cênico similar se aplica à $\boldsymbol{C o d a}$. Após a apresentação da última personagem incorporada - Diva do Recitativo $\mathrm{pp} /$ Diva do Recitativo ff, correspondente ao motivo "Sono canti" (veja fotograma "j" na Figura 7) -, a indumentária cênica é imediatamente recondicionada como o "véu fúnebre", e Martha Herr realiza o percurso inverso da Introdução, ao mesmo tempo em que vai se desvencilhando da caracterização: o "véu", largado ao chão no meio do percurso (na Figura 6, Circumplexo "f", veja a seta verde entre os quadrantes IV e III; e, na Figura 7, veja a sequência dos fotogramas "l”, "m”, “n”, "o"). O ritual cênico, que pelo despir-se e livrar-se do tecido negro sugere uma progressiva desincorporação das personagens imaginárias atuantes na performance, é acompanhado pelos prescritos efeitos vocais de inspiração ruidosa intercalados de silêncios cada vez mais longos.

Durante a cena, o espectador certamente perceberá a progressiva dissipação do sentimento de "angústia" que parece relacionar-se ao tecido negro e que se multiplicara

\footnotetext{
${ }^{6}$ Ao tecido negro Martha Herr atribui significados diferentes, e com ele ela constrói as várias personagens que interpreta (v. fotogramas “e”, “f”, “g”, "h", “i”, “j”, "k” no lado direito da Figura 7). Nestas construções, ela o metamorfoseia em "véu fúnebre”, "xador", "bandeira de manifesto", “echarpe” (ou "luvas”), "capa de super-herói" (ou "manto de uma deusa") e, até mesmo, minimiza sua função (na interpretação do Cantadô Nordestino).

${ }^{7}$ A intensa alternância de motivos e sua sequência ilógica não permitem a memorização da peça, prendendo a intérprete diante da partitura durante a performance. Martha ainda se desvencilha desse restrito espaço cênico nas pequenas seções de Introdução e na Coda, que são mais fáceis de se memorizar.
} 
em distintas nuances afetivas relativas aos diferentes motivos-personagens ${ }^{8}$. A cena sugere uma despedida serena e despreocupada. Entretanto, nota-se uma hesitação no andar da intérprete, uma atitude de desconfiança na linguagem corporal, expressa pela mão esquerda que repousa interrogativamente no queixo (fotograma " $n$ " da Figura 7). Então, como num filme de terror, ela se vira subitamente para o pano negro que já não lhe é familiar, e se assusta com o que vê. Ato contínuo, em desespero, levanta os braços, arregala os olhos, abre a boca (índices das emoções "surpresa" e "medo"; EKMAN; FRIESEN, 2002, cap. 4 e 5) e solta um grito de pavor (fotograma "o" da Figura 7).

Este efeito criado por Martha, ao mesmo tempo em que ratifica a sugestão de "desincorporação" da última personagem assumida, muda o caráter conclusivo da peça. Completamente inesperado, o Grito de pavor, que substitui o motivo da Inspiração (na partitura), surpreende o espectador, imprimindo na cena final uma comicidade dramática completamente compatível com muitos momentos da performance em que a representação cênica se revela caricaturesca, impregnada de um irônico humor paródico.

\section{2 - A Personagem Narradora}

Conforme já consideramos, os efeitos vocais da Introdução (a inspiração ruidosa e a expiração ruidosa) são expressões da "voz narrativa", representando um narradorpersonagem que tanto narra quanto participa da história ${ }^{9}$. Se a introdução de uma narrativa, em regra geral, serve ao propósito da apresentação de personagens, a Introdução de Cantos serve à apresentação da única personagem real (uma cantora-atriz), cuja história - nossa versão - desenha o perfil de um estado mental esquizofrênico, desestruturado, caracterizado por fenômenos de despersonalização e alucinações discerníveis nos vários cantos que se embaralham na mente da personagem, desagregando-a. Expressando-se unicamente em ruídos de inspiração entremeados de

\footnotetext{
${ }^{8}$ Lembramos aqui o significado que a "angústia" tem na psicanálise lacaniana. Segundo Lacan, a angústia "é uma espécie de matriz fundamental dos afetos, do qual todos os outros afetos são variações, deformações e supressões" (BEIVIDAS; DUNKER; RAVANELLO, 2018, p. 174). É justamente essa matriz que julgamos estar representada nos motivos assemânticos da personagem narradora, conduzindo às variantes afetivas que se expressam nos diferentes motivos semânticos. No modelo circumplexo, consideramos que a "angústia", assim como o motivo Silêncio, poderiam estar representados no ponto de confluência dos eixos horizontal e vertical. As emoções que a expressam (no caso da personagem narradora de Cantos, "surpresa", "expectativa" e "fadiga") mobilizam-se no sentido do prazer/desprazer ou ativação/desativação. ${ }^{9}$ Em termos de emoção, o Silêncio na interpretação de Martha Herr sugere nuanças de "expectativa", precedendo tanto a ativação ou desativação, quanto o prazer ou desprazer.
} 
silêncios, a narrativa assemântica da Introdução de Cantos projeta-se como um discurso de emoções. A expressão vocal e a corporal são coadjuvantes na comunicação do que se apresenta: a manifestação de um transtorno psíquico que revela, principalmente, a "angústia" de quem vive refém das fantasias.

Adiante da Introdução, em toda a evolução da possível trama, dando continuidade ao seu discurso narrativo, a Narradora emerge e submerge entre as vozes fantasmas que habitam a sua mente, multiplicando os afetos que derivam da sua "angústia". Como Martha Herr comunica isto? Como voz e corpo se integram na função discursiva? Como ela semantiza o afeto, tornando-o um significante? Como transmite "medo" ou "exaustão" apenas inspirando e expirando? Observemo-la encher e esvaziar os pulmões ao tempo em que eleva e desce a cabeça entre os planos médio (fotograma "a" da Figura 8, em [0:40]) e o plano médio-baixo (fotograma "b" da Figura 8, em [0:41]), o que é acentuado pela expressão de seus olhos (arregalados), testa (contraída para cima), e boca (maxilar inferior caído) (EKMAN; FRIESEN, 2002, cap. 4; índice da emoção "surpresa"). Depois, fechando os olhos e a boca, numa expressão de "alívio" e/ou "cansaço".

Figura 8 - Realização do motivo Inspiração (fotograma a) com a expressão de "surpresa" (cabeça elevada, testa contraída para cima, olhos arregalados e boca aberta) e do motivo Expiração (fotograma b) com a expressão de "alívio" (cabeça baixa, olhos semicerrados, testa relaxada e boca relaxada).
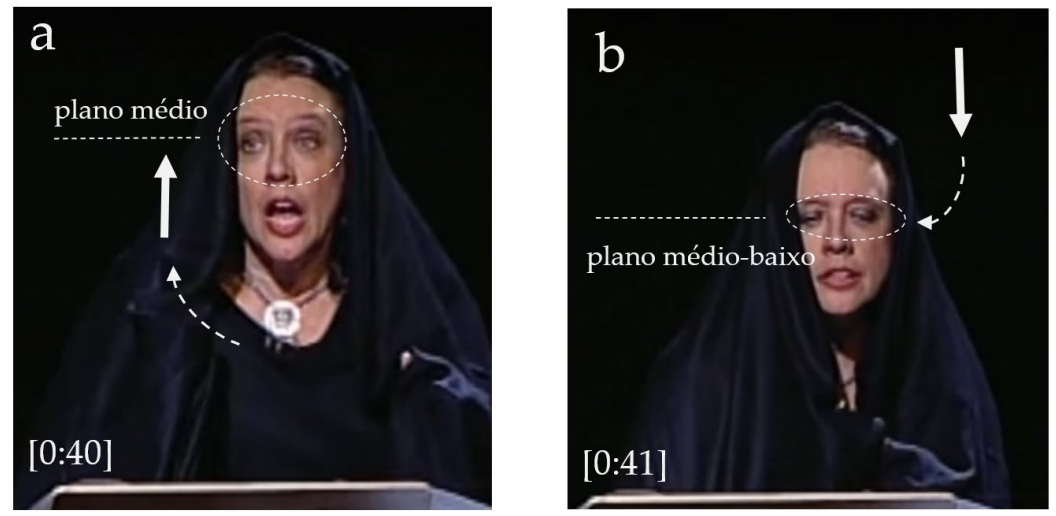

Fonte: HERR; RESCALA, 2008.

Observemo-la também na busca de gradações exageradas do efeito vocal, em [3:06], quando move lenta e lateralmente o tronco para encher os pulmões, assim aumentando muito o nível de ruído da voz, como se estivesse com falta de ar (fotograma “a" da Figura 9), encenando "expectativa". Ou em [3:16], quando prende a respiração por 
cerca de 3 segundos, arregala os olhos e contrai a boca e pescoço interrogativamente (fotograma "b" da Figura 9), em outra encenação de "expectativa".

Figura 9 - Encenações de Martha Herr sugerindo expectativa.
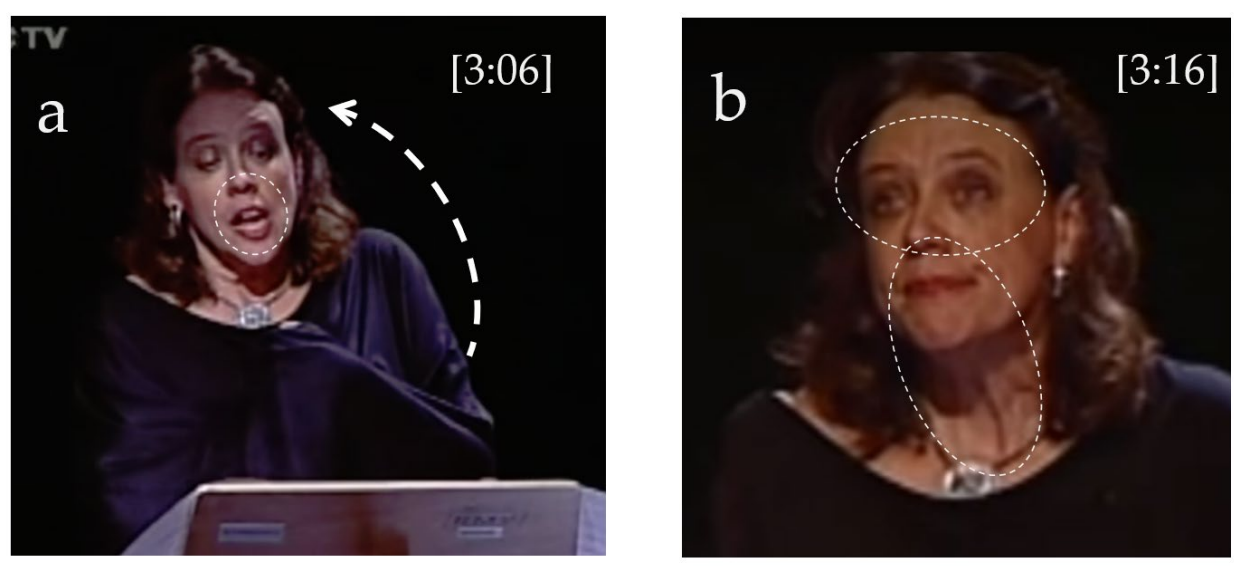

Fonte: HERR; RESCALA, 2008.

\section{3 - A Carpideira}

A primeira das personagens incorporadas (imaginárias), a Carpideira, é a mais recorrente na primeira parte da narrativa (Seç̃̃es $\boldsymbol{A}$ e $\boldsymbol{B})$. Para compô-la, Martha Herr se utiliza de três recursos cênicos: indumentária, atitude corporal e contração da cinesfera. O pano negro sobre a cabeça recolhida se transforma em um "véu fúnebre" que ora procura esconder o rosto (Figura 10, fotograma "a"), ora o revela com sua contrição (Figura 10, fotograma "b"). Cabisbaixa e encolhida, em postura concêntrica, ela ocupa o plano médio do espaço cênico, inscrevendo-se entre dois objetos icônicos do cenário: um sino de bronze pendido no plano alto, cuja sombra se projeta no fundo do palco, e um vaso com flores no plano médio-baixo. A cena lúgubre remete a uma religiosidade mística e provinciana. Papéis amassados e espalhados no chão (Figura 10, fotograma "a"), podem não contribuir com o cenário fúnebre, mas sugerem uma referência ao caos mental da Narradora (a personagem real). Sem pranto nem endechas, a Carpideira de Rescala reza fervorosa e concentradamente uma Ave Maria quase inaudível. Seu rosto angustiado tem uma expressão tensa e constrangida, sugerindo a emoção do "medo" (fotograma "b" da Figura 10; veja os músculos da testa e da boca contraídos para o centro do rosto). 
Figura 10 - Planos cênicos, expressões faciais, movimentos corporais e objetos de cena da personagem Carpideira.
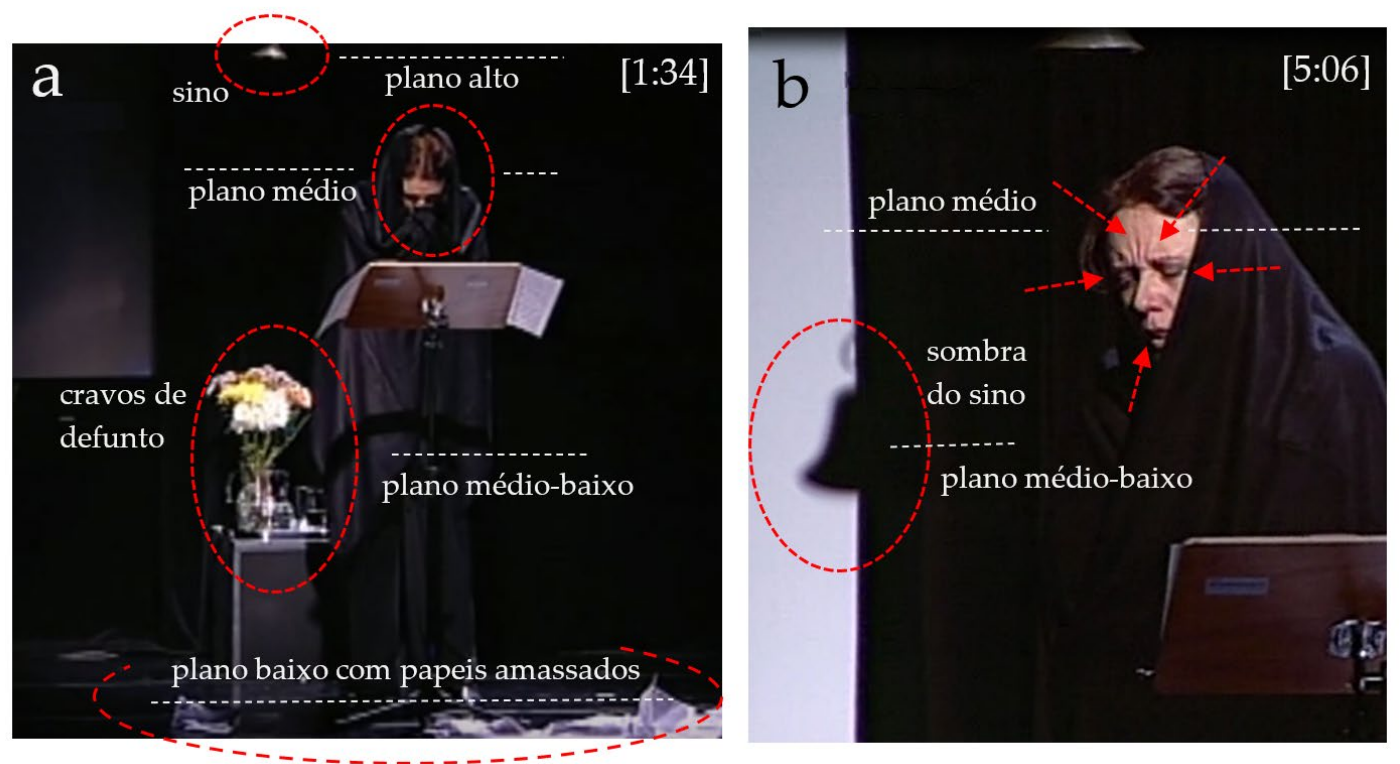

Fonte: HERR; RESCALA, 2008.

\section{4 - A Diva do Bel Canto}

A segunda personagem imaginária a surgir em cena, contracenando com a Carpideira, refere-se ao motivo "Oh, voz homines", configurado na região mais aguda (registro 5) e na dinâmica mais intensa ( $f$ ) da peça. Justificando nossa denominação (Divaa do Bel Canto), sua encenação busca exacerbar o contraste com a Reza sussurrada da Carpideira. Para isto, como estratégia de ocupação do palco (LABAN, 1978, p. 69), Martha Herr abre os braços, extrovertida, expandindo sua cinesfera no plano alto do espaço cênico e estendendo o pano, que de "véu" se transforma numa espécie de "bandeira de manifesto". Durante o diálogo das duas personagens, é intensa a intermitência entre fechar e abrir os braços, encolher e estender o dorso/tórax, fechar e abrir a indumentária, (compare-se as Figuras 10 e 11). Pode-se dizer que a exaltação "vocativa" da personagem cantante pede atenção ao drama da personagem murmurante.

Quanto ao tipo de execução vocal, Martha Herr decide colocar o timbre imponente do bel canto em evidência. O canhão de luz aberto sobre seu rosto contra o fundo escuro do tecido negro reforça a ideia de uma figura impactante que, com sua voz enérgica e atitude imperativa, parece conclamar, convocar, exortar, ações que podem representar um estado emocional de "euforia". 
Figura 11 - A cinesfera máxima de Martha Herr na personagem Diva do Bel Canto, com o pano preto transformado em "bandeira de manifesto".

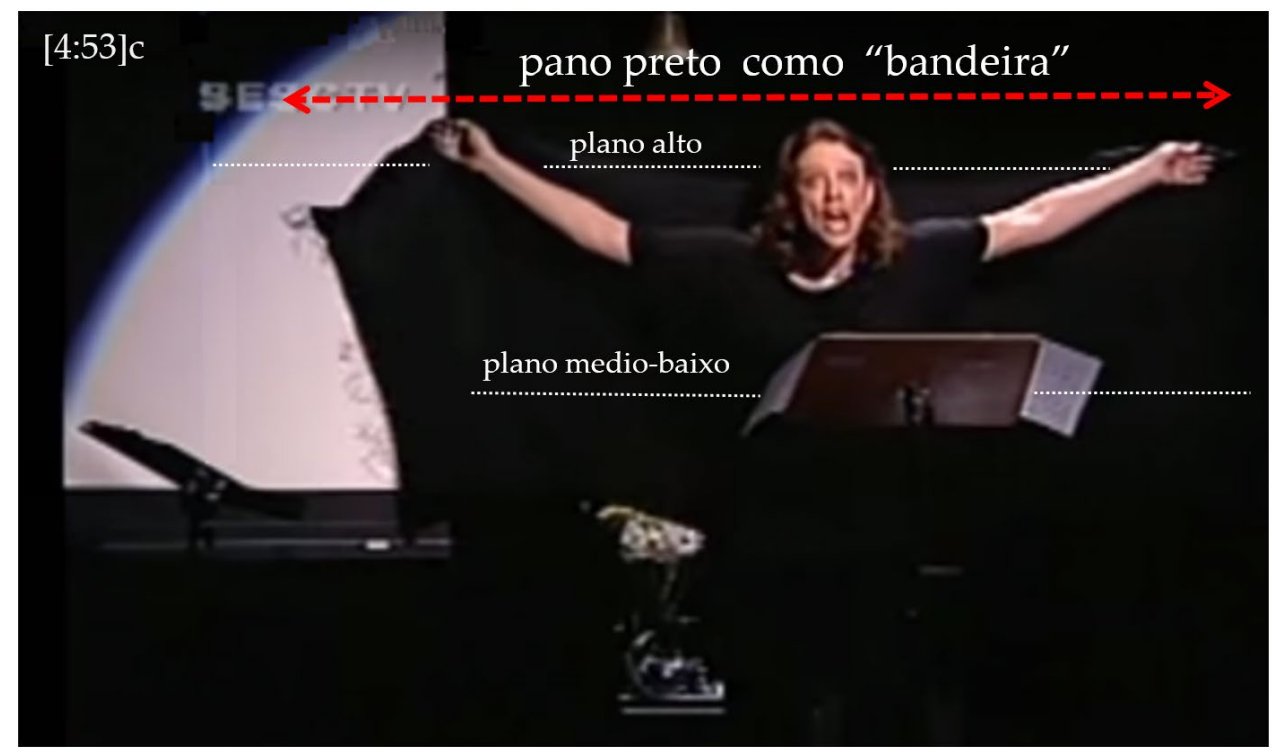

Fonte: HERR; RESCALA, 2008.

\section{5 - A Árabe Microtonal}

A personagem Árabe Microtonal personifica o motivo Vocalise " $a$ ", que Martha não pronuncia com a vogal aberta “ $a . .$. ”, optando por fazer um “é...” bastante anasalado. Ao mesmo tempo em que transforma o pano preto em "xador" (peça do vestuário feminino muçulmano que envolve o corpo todo, com exceção dos olhos), ela canta um fragmento baseado no sistema maqan (modos melódicos da música árabe; ALVES, 1989, p. 83-91). O fotograma "a" da Figura 12 mostra a estratégia da cantora de contrair músculos ao redor do nariz para produzir, com o Vocalise "थe", a sonoridade nasal associada ao canto do Oriente Médio. Tremendo a cabeça em gestos laterais muito curtos e rápidos (como indicado no fotograma "b" da Figura 12), Martha facilita a realização dos arabescos típicos do canto árabe, semelhantes a trinados microtonais. A encenação exagerada (e até mesmo irônica, no tremular de cabeça) desse estereótipo cultural exótico ao contexto dos demais cantos da peça (italiano, francês, norte-americano e brasileiro), funciona como um gatilho para o "humor", disparando gargalhadas no público. A atitude positiva da Árabe Microtonal parece derivar-se da emoção "alegria", com notas de "humor" e, para nossos padrões ocidentais, "mistério". 
Figura 12 - Na encenação da personagem Árabe Microtonal, contrações faciais (fotograma "a”) e movimentos laterais de cabeça (fotograma "b") favorecem os sons nasais e microtonais; na simulação do "xador" (fotograma "b"), Martha Herr esconde mãos e parte do rosto.
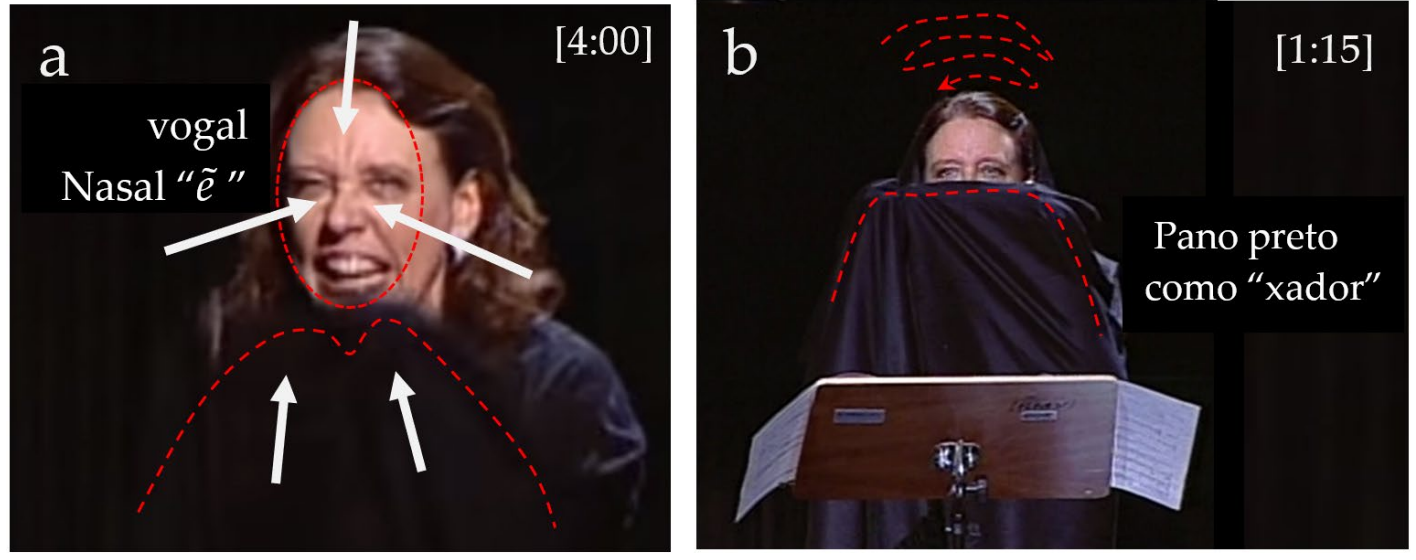

Fonte: HERR; RESCALA, 2008

\section{6 - A Diva do Jazz}

A partir da Seção $\boldsymbol{B}$ (iniciada aos [1:39] da performance), outras personagens entram em cena, aumentando o redemoinho de emoções que se emaranham desordenadamente. A pequena pausa indicada na partitura para definir uma nova seção (uma fermata) é interpretada por Martha Herr como uma lenta recaracterização da indumentária, para introduzir uma nova personagem: a Diva do Jazz. Para sugerir a entrada da nova personagem, a intérprete recorre ao pano preto, usando-o à maneira de "capa de super-herói” ou "manto de uma deusa" lançado dramática e velozmente à frente de seu corpo, gesto também sublinhado no rosto pelo olhar agressivo e penetrante (fotograma "c" da Figura 13, em [4:16]).

A personagem, que corresponde ao estereótipo da mulher norte-americana autoconfiante, é configurada com expressões faciais que incluem o rosto elevado com ar de superioridade (o "nariz-em-pé", típico da arrogância), refletindo as emoções básicas do "nojo" e da "raiva" (EKMAN; FRIESEN, 2003, Exemplos 25 e 29b). No seu rosto também se esboçam ora sarcasmo (os olhos semicerrados e um semi-sorriso ocupando apenas metade da boca; fotograma "a" da Figura 13, em [2:10]), ora uma agressividade que combina o cenho franzido ao centro da testa com os cantos da boca caídos (fotograma "b" da Figura 13, em [1:57]).

A realização do motivo "Singing the song", no registro grave da voz feminina, possivelmente insinuando a potência típica da realização vocal de cantoras de blues, 
requer esforço de adaptação do timbre lírico de Martha Herr, o que ela não deixa de demonstrar com algumas de suas intervenções irônicas (por exemplo, aos [2:10]), provocando comicidade e imediata reação da plateia.

Figura 13 - Sarcasmo (fotograma “a"), arrogância (fotograma "b”) e agressividade (fotograma “c”) na encenação da personagem Diva do Jazz por Martha Herr.
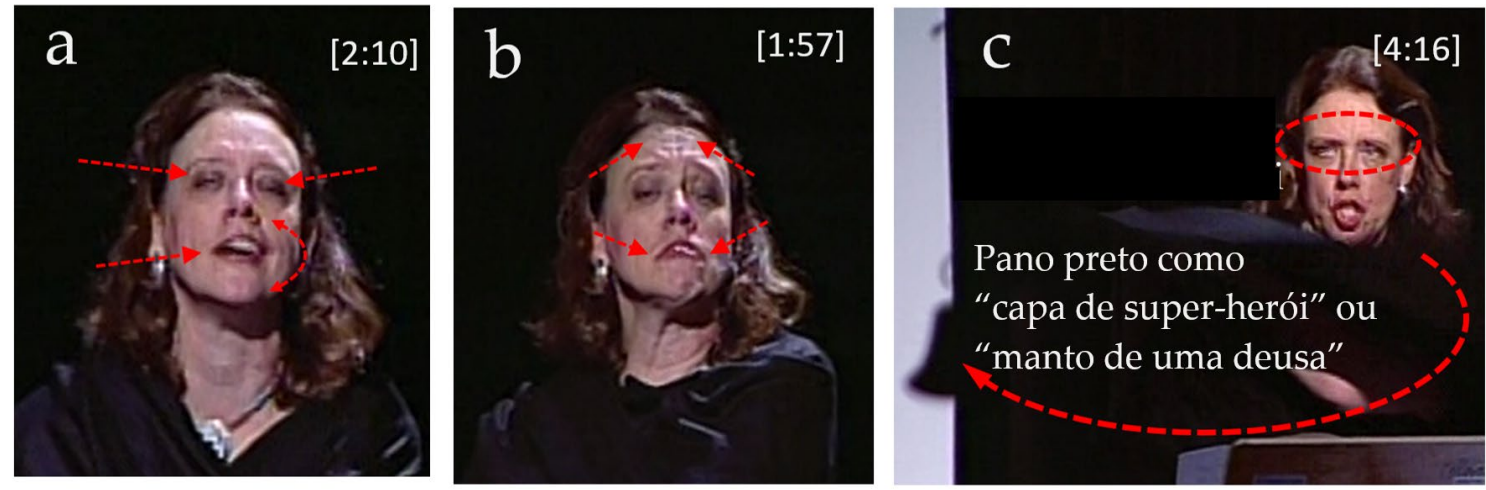

Fonte: HERR; RESCALA, 2008.

\section{7 - A Diva da Chanson}

A partir do motivo "Ma chanson d'amour", Martha Herr constrói a Diva da Chanson, personagem que mais se localiza à direita no lado do prazer do Eixo PrazerDesprazer no Circumplexo de Russell. Apesar de abrigar-se numa cinesfera um tanto contida, esta personagem projeta a sensualidade da mulher francesa em diferentes aspectos (Figura 14): na expressão facial (o "biquinho" formado pela contração dos lábios no centro da boca, quando canta a sonoridade "u" de "amour"); em efeitos de dicção (exagerando a pronúncia dos sons característicos da língua francesa, no anasalamento na palavra chanson ou na aspereza do " $\mathrm{r}$ " gargarejado e exageradamente alongado de amourrrr...); e na atitude corporal (as mãos elegantemente apoiadas na cintura com o pano preto transformado em "echarpe" ou sugerindo, vez ou outra, "luvas" longas de dedos cortados e o posicionamento de um dos ombros à frente do corpo, em pose de modelo de desfile). O contexto "amour" se reflete em nuanças de prazer sutis e de baixa ativação da emoção "alegria", revelando um estado de sóbrio encantamento. 
Figura 14 - A Diva da Chanson: sensualidade da mulher francesa reveladas na expressão labial, na atitude corporal do ombro levado à frente (fotograma a), nos olhos cerrados (fotograma b).
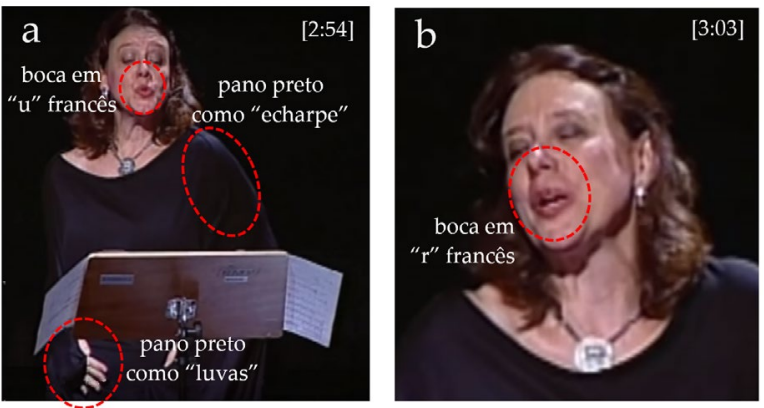

Fonte: HERR; RESCALA, 2008.

\section{8 - A Diva do Recitativo}

As $\operatorname{Seçães~} \boldsymbol{A}$ e $\boldsymbol{B}$ não se distinguem funcionalmente no que tange ao processo narrativo da peça, podendo ser consideradas juntas como um grande "desenvolvimento" progressivamente acelerado e atropelado da ação conflitante das personagens. Ação esta que, antes de sugerir intercomunicabilidade, mais sugere a adjunção de personagens encapsuladas, sem se dar conta da alteridade. Isto leva à exaustão da narração, tal como se revela na única realização prolongada do motivo Inspiração - um momento climático da narrativa (em [3:06] ${ }^{10}$. Assim, a Seção $\boldsymbol{C}$ indica uma nova funcionalidade narrativa, que podemos relacionar à "conclusão" ou "desfecho", encerrando um entendimento para o conflito dramático.

Esse entendimento se projeta através do motivo "Sono canti", o mais desenvolvido no sentido semântico: "Sono canti de tris[tezza], sono canti d'a[more]; "Per cantare tutti questi canti", etc. Consideramos que estes fragmentos de texto, sugerindo uma interconexão lógica, representam um estado de lucidez sobre o desvario anterior: são cantos de tristeza ou de amor para serem cantados. O momento, portanto, é o da conscientização/revelação da verdade. A personagem cônscia, que tem uma explicação para a confusa interatividade de vozes, parece cumprir a função de "evangelista", que “anuncia uma boa nova”. Este anúncio provê uma virada semântica no plano narrativo, projetando-se como uma reflexão conclusiva.

\footnotetext{
${ }^{10}$ Ao final do denso e intenso intercâmbio motívico da Seção $\boldsymbol{B}$, a personagem Narradora tem aí, até então, o ponto mais tenso de sua narrativa.
} 
A dupla configuração musical do motivo "Sono canti" (em fala sussurrada e vocalizada, ambas em $p p$ ) suscita em Martha duas atitudes interpretativas contrastantes e intermitentes. Se Martha mantém a fala sussurrada em baixa intensidade (tal como prescrita), nas partes de fala vocalizada ela transgride a dinâmica indicada na partitura, realizando-as no extremo oposto, em $f f$. $\mathrm{O}$ motivo modificado, então, dá lugar à personagem Diva do Recitativo ff, que, em máxima cinesfera, lança mão do pano negro usando-o novamente tal como uma "bandeira de manifesto" (Figura 15a). Nas falas sussurradas, a Diva do Recitativo pp (espécie de alter ego da Diva do Recitativo ff) se recolhe a uma cinesfera mínima, abaixando a cabeça para dentro do plano médio-baixo, levando as mãos ao redor da boca, num gesto de quem segreda ao espectador (Figura 15b). Enquanto a Diva do Recitativo ff parece "anunciar uma boa nova" ao mundo (dada a amplitude da sonoridade e da cinesfera), a Diva do Recitativo pp se dirige ao espectador.

Apesar da postura corporal e da qualidade da emissão vocal polarizadas, as duas versões da Diva do Recitativo transmitem uma firme liderança com postura vocal de comando sobre o que se espera que aconteça (a saída do estado psíquico de surto esquizofrênico). A polarização na interpretação vocal e corporal, por sua vez, revelam nuances distintas de "euforia": contida (sussurrada em $p p$ ) ou exaltada (falada em $f f$ ).

Pode-se dizer que a Diva do Recitativo ff é uma interferência criativa notável de Martha Herr, que amplia significativamente a dramatização na $\mathbf{S e c ̧ a ̃ o ~} \boldsymbol{C}$. As alternâncias entre sussurros e brados de fragmentos cada vez mais curtos do motivo "Sono canti" conduzem a um final climático, quando a atriz conclama "Canta, canta, mai, mai!"

Figura 15 - Uma personagem com duas atitudes: uma altiva, a Diva do Recitativo ff (fotograma "a") e outra contida, a Diva do Recitativo pp (fotograma "b").
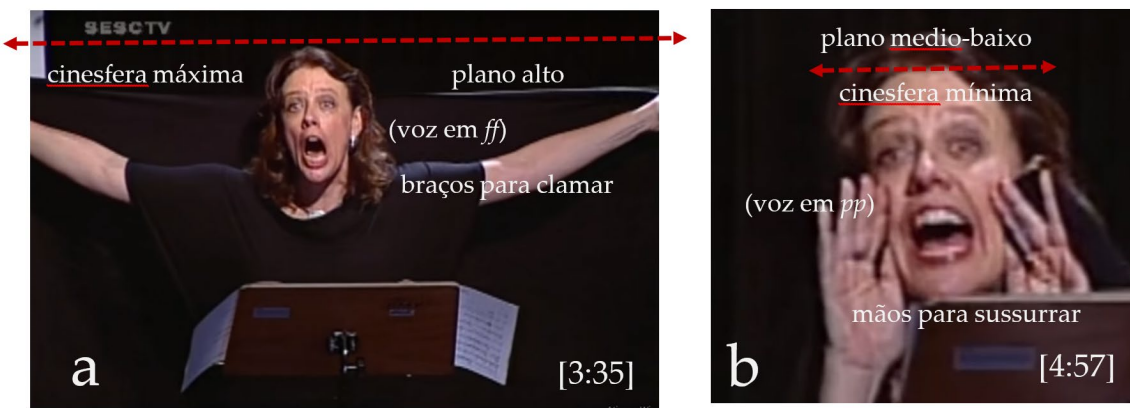

Fonte: HERR; RESCALA, 2008. 


\section{9 - O Cantadô Nordestino}

O motivo "Ai, cantador" é o menos presente na peça, ocorrendo apenas três vezes na $\boldsymbol{S e c ̧ a ̃ o ~} \boldsymbol{C}$ e uma vez na $\boldsymbol{C o d a}$. Na sua realização vocal, Martha Herr se afasta de referências da música erudita ao utilizar uma voz menos lírica, com menos vibrato, menos impostação (modulando a cobertura vocal com um abaixamento mais discreto da glote) e, consequentemente, menor ressonância do trato vocal para compor a personagem Cantadô Nordestino (PACHECO, MARÇAL e PINHO, 2004, p. 430-432).

Balançando singelamente o tronco de um lado para o outro numa simplicidade ingênua que parece ter brotado da emoção "tristeza", com o pano preto sobre os ombros de forma não emblemática (Figura 16), a intérprete cria nuances emotivas que podem insinuar "resignação" e "nostalgia" (subjetivando a interjeição "Ai,..."), tão comuns em caracterizações do semblante sertanejo.

Figura 16 - Martha Herr interpreta a "resignação" e a "nostalgia" do Cantadô Nordestino.

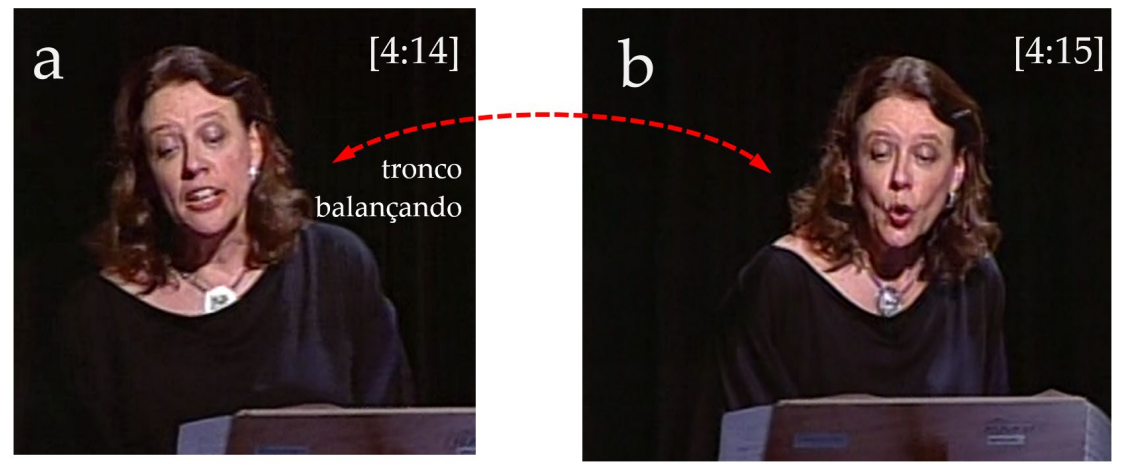

Fonte: HERR; RESCALA, 2008.

\section{5 - A versatilidade e a criatividade de Martha Herr}

O alto grau de virtuosismo de Martha Herr pode ser verificado quando se constata que ela alterna entre múltiplos personagens 180 vezes durante 5 minutos e 25 segundos. Ao mesmo tempo em que segue o script original do compositor (a partitura), ela personaliza a performance acrescentando efeitos vocais, alterando prescrições dinâmicas, assim criando significados subliminares que se multiplicam no refinamento dos detalhes expressivos para configurar afetivamente cada personagem (veja o Quadro Sinóptico abaixo), observados tanto no uso da voz quanto do corpo, do objeto cênico central e do palco. 
Além das encenações no início e no final da peça e da interpretação ambígua do motivo "Sono canti, ampliando significativamente a dramatização de Cantos, outra interferência criativa notável de Martha encontra-se no final da peça, quando ela substitui a última Inspiração por um Grito de pavor, compondo uma cena tipicamente hitchcockiana. Com a substituição da inspiração pelo grito, Martha Herr provê um final para a narrativa que não condiz mais com a sugestão de permanência do transtorno psíquico (ao final da partitura): desincorporadas todas as personagens representadas, a personagem Narradora - a intérprete - sugere sua desvinculação do transtorno mental que tão bem representou. A Figura 17 projeta uma espécie de mapa analítico da $\boldsymbol{S e c ̧ a ̃ o ~} \boldsymbol{C}$ + Coda, dos pontos de vista da composição (partitura) e da realização criativa de Martha Herr.

Quadro Sinóptico - Os 10 motivos de Cantos com respectivas ocorrências, antropomorfizações (personagens) e interpretação (expressão corporal, indumentária e emoções) de Martha Herr.

\begin{tabular}{|c|c|c|c|c|}
\hline $\begin{array}{l}\text { Motivos } \\
(10)\end{array}$ & $\begin{array}{l}\text { Ocorrências } \\
(180)\end{array}$ & $\begin{array}{l}\text { Personagens } \\
\text { (9) }\end{array}$ & $\begin{array}{l}\text { Simbologia corporal } \\
\text { (gestos, expressões faciais, } \\
\text { indumentária) }\end{array}$ & $\begin{array}{l}\text { Interpretação emocional } \\
\text { dos "afetos nucleares" }\end{array}$ \\
\hline Silêncio & 12 & \multirow[t]{3}{*}{ Narradora } & neutralidade & $\begin{array}{c}\text { "angústia" } \\
\text { apreensão; expectativa }\end{array}$ \\
\hline Expiração & 8 & & cinesfera retraída & $\begin{array}{c}\text { "cansaço" } \\
\text { alívio }\end{array}$ \\
\hline Inspiração & 53 & & cinesfera expandida & $\begin{array}{l}\text { "tensão" } \\
\text { surpresa } \\
\end{array}$ \\
\hline $\begin{array}{l}\text { Reza } \\
\text { sussurrada }\end{array}$ & 27 & Carpideira & $\begin{array}{l}\text { cinesfera retraída; cabeça } \\
\text { abaixada; rosto contraído; } \\
\text { "véu fúnebre" }\end{array}$ & $\begin{array}{l}\text { "tristeza" } \\
\text { medo }\end{array}$ \\
\hline \multirow[t]{2}{*}{$\begin{array}{l}\text { "Sono } \\
\text { canti" }\end{array}$} & 12 & $\begin{array}{l}\text { Diva do } \\
\text { Recitativo pp }\end{array}$ & $\begin{array}{l}\text { cinesfera retraída; boca, } \\
\text { olhos e mãos que segredam }\end{array}$ & $\begin{array}{l}\text { "contentamento" } \\
\text { euforia contida }\end{array}$ \\
\hline & 12 & $\begin{array}{l}\text { Diva do } \\
\text { Recitativo ff }\end{array}$ & $\begin{array}{l}\text { cinesfera expandida; braços } \\
\text { que clamam, "bandeira de } \\
\text { manifesto"" }\end{array}$ & $\begin{array}{c}\text { "entusiasmo" } \\
\text { euforia excitada }\end{array}$ \\
\hline $\begin{array}{l}\text { "Ai, } \\
\text { cantador" }\end{array}$ & 4 & $\begin{array}{l}\text { Cantadô } \\
\text { Nordestino }\end{array}$ & $\begin{array}{l}\text { Sutil balanço lateral de } \\
\text { cabeça/tronco }\end{array}$ & $\begin{array}{c}\text { "cansaço" } \\
\text { resignação; nostalgia }\end{array}$ \\
\hline $\begin{array}{l}\text { Vocalise } \\
\text { " } a \text { " }\end{array}$ & 12 & $\begin{array}{l}\text { Árabe } \\
\text { Microtonal }\end{array}$ & $\begin{array}{l}\text { testa contraída; nariz } \\
\text { contraído; "xador" }\end{array}$ & $\begin{array}{l}\text { "felicidade" } \\
\text { alegria; humor }\end{array}$ \\
\hline $\begin{array}{l}\text { "Ma } \\
\text { chanson } \\
\text { d'amour" }\end{array}$ & 7 & $\begin{array}{l}\text { Diva da } \\
\text { Chanson }\end{array}$ & $\begin{array}{l}\text { cabeça elevada, ombro à } \\
\text { frente, mão na cintura, } \\
\text { "echarpe", "luvas" }\end{array}$ & $\begin{array}{l}\text { "contentamento" } \\
\text { encantamento }\end{array}$ \\
\hline $\begin{array}{l}\text { "Singing the } \\
\text { song" }\end{array}$ & 12 & Diva do Jazz & $\begin{array}{l}\text { cabeça elevada; comissuras } \\
\text { caídas; "capa" / "manto" }\end{array}$ & $\begin{array}{l}\text { "chateação" } \\
\text { nojo; raiva }\end{array}$ \\
\hline $\begin{array}{l}\text { "Oh, voz } \\
\text { homines" }\end{array}$ & 21 & $\begin{array}{l}\text { Diva do Bel } \\
\text { Canto }\end{array}$ & $\begin{array}{l}\text { cinesfera expandida; } \\
\text { "bandeira de manifesto" }\end{array}$ & $\begin{array}{c}\text { "entusiasmo" } \\
\text { euforia }\end{array}$ \\
\hline
\end{tabular}

Fonte: elaboração dos autores. 
Figura 17 - Comparação entre os desfechos de Cantos (Seção C + Coda) na partitura de Tim Rescala e na interpretação de Martha Herr, em que a cantora-atriz (1) altera dinâmica e timbre do motivo "Sono canti" e (2) substitui o motivo Inspiração por um Grito de Pavor.
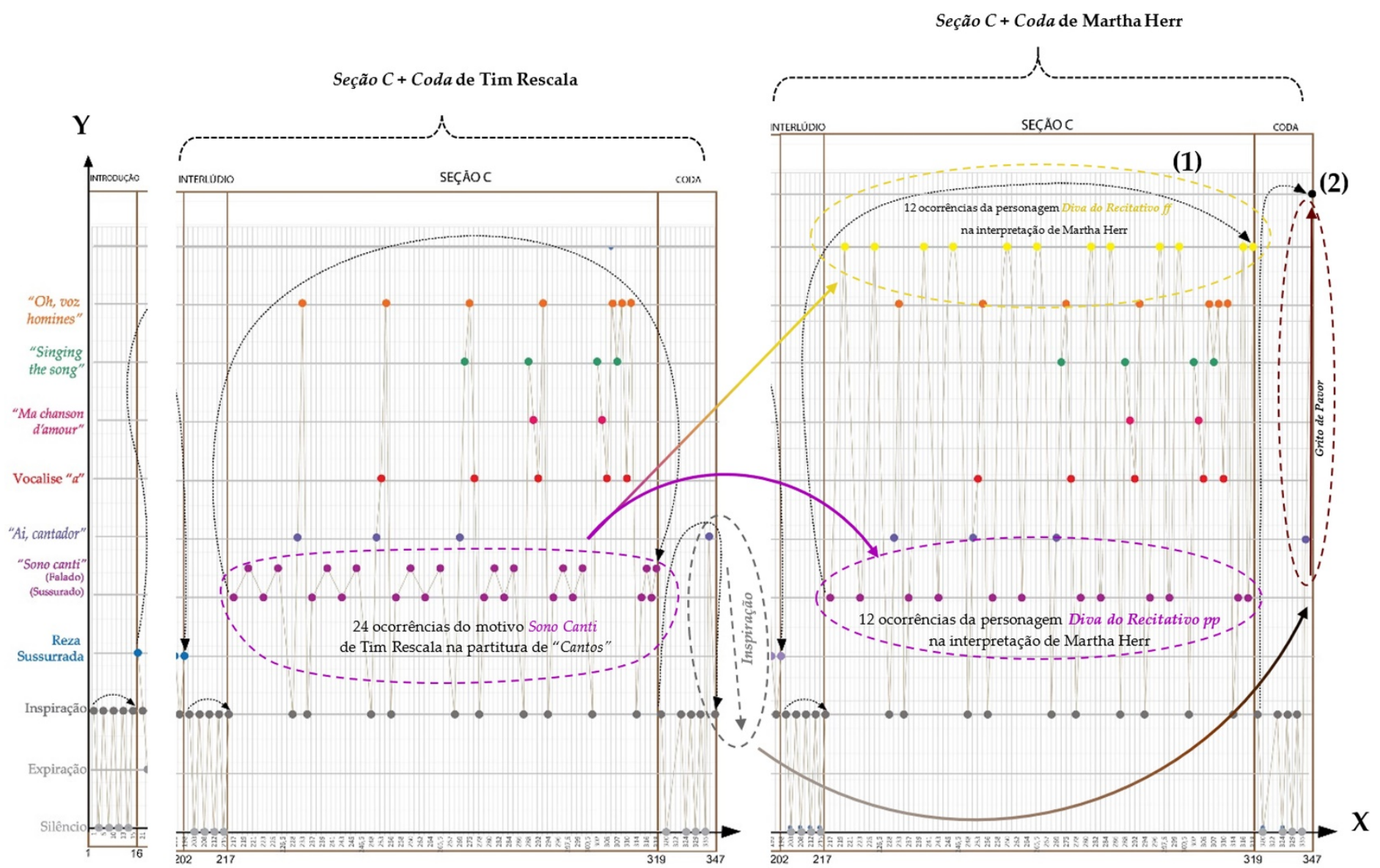

Fonte: elaboração dos autores. 
Observando o vídeo, pode-se também notar como a intérprete contracena com a iluminação de palco, explorando focos de luz e sombras, contraindo e expandindo sua cinesfera. Sua encenação, integrando voz, expressões faciais, gestos de cabeça, tronco, braços e pernas, aliada aos objetos de cena (sino, vaso de flores, papeis amassados e, principalmente, o pano preto), à iluminação e sombras de Iacov Hillel e à cinematografia de Carlos Travaglia, resultaram em um rico, coeso e instigante amálgama do trinômio texto-música-imagem. Em seu desafiante e vertiginoso discurso, eminentemente polifônico, Martha Herr realiza no palco, sozinha, o equivalente a um coro de câmara, cujos divisi entre os muitos personagens e encenações é regido por uma maestrina que transborda excelência ao enfrentar as demandas virtuosísticas de Cantos.

\section{Referências de texto}

ALMÉN, Byron. Narrative Archetypes: A Critique, Theory, and Method of Narrative Analysis. Journal of Music Theory, v. 47, n. 1, p. 1-39, 2003.

ALVES, José A. C. A Tentação do ocidente. In: Arabesco: da música árabe e da música portuguesa. Cap. 7. Lisboa: Assírio \& Alvim, p. 83-91, 1989.

BEEBE, Beatrice; KNOBLAU, Steven; RUSTIN, Judith; SORTER, Dorienne. A Comparison of Meltzoff, Trevarthen, and Stern. Psychoanalytic Dialogues. Symposium on Intersubjectivity in Infant Research and its Implications for Adult Treatment. In: https://www.researchgate.net/publication/238319282_A_Comparison_of_Meltzoff_Trevarthen_ and_Stern Part I, v. 13, n. 6, p. 809-836, 2003.

BEIVIDAS, Waldir; DUNKER, Christian; RAVANELlO, Tiago. Para uma concepção discursiva dos afetos: Lacan e a semiótica tensiva. Psicologia: Ciência e Profissão, v. 38 n. 1, 2018, p. 172-185.

BORÉM, Fausto. A Cinesfera da Voz e do Corpo da Cantora-atriz Martha Herr. In: Corporeidade e Educação Musical. Patrícia Furst Santiago, Betânia Parizzi e Jussara Fernandino (org.). Belo Horizonte: Centro de Musicalização Integrado da UFMG, 2017, p. 71-95.

BORÉM, Fausto. MaPA e EdiPA: duas ferramentas analíticas para as relações texto-som-imagem em vídeos de música. Musica Theorica, v. 1, n. 1, 2016, p. 1-37. São Paulo: TeMA/USP.

BORÉM, Fausto; NOGUEIRA, Ilza. A Corporalidade musical de Martha Herr: versatilidade, crítica e humor. In: Anais do $2^{\circ}$ Congresso da Associação Brasileira de Teoria e Análise Musical, 2017, Florianópolis, UDESC, p. 104-117.

BORÉM, Fausto; TAGLIANETTI, Ana Paula. Construção de uma performance cênica para as três modinhas imperiais de Lino José Nunes (1789-1847). Opus, v. 22, n. 2. São Paulo, 2016, p. 193-215.

BORÉM, Fausto; TAGLIANETTI, Ana Paula. A trajetória cênico-musical de Elis Regina. Per Musi. n. 29. Belo Horizonte: UFMG, 2014, p. 39-52. 
CHION, Michel. Audio-Vision Sound on Screen. Tradução para o inglês de Claudia Gorbman. New York: Columbia University Press, 1994.

CRISPIM, Ana Carla; CRUZ, Roberto M.; OLIVEIRA, Cassandra M.; ARCHER, Aline B. O Afeto sob a perspectiva do circumplexo: evidências de validade de construto. Avaliação psicológica, v. 16, n. 2, abr./jun. 2017, p. 145-152.

Disponível em: http://pepsic.bvsalud.org/pdf/avp/v16n2/v16n2a05.pdf. Acesso em 30 mai. 2020.

EEROLA, Tuomas. Three Controversies of Music and Emotions: Neuroscience and Psychology of Sadness and Music. In: The Routledge Companion of Music, Mind and Well-being. Ed. by Penelope Gouk, James Kennaway, Jacomien Prins and Wiebke Thormählen. New York: Routledge, 2018, p. 219-234.

EKMAN, Paul. What Scientists Who Study Emotion Agree About. Perspectives on Psychological Science, v. 11, n. 1, 2016, p. 31-34.

EKMAN, Paul. An Argument for Basic Emotions. Cognition and Emotion, v.6, n. 3/4, 1992, p. 169-200.

EKMAN, Paul. Universals and Cultural Differences in Facial Expressions of Emotion. In: Nebraska Symposium on Motivation. J. K. Cole (ed.), v. 19. Lincoln: University of Nebraska Press, 1972.

EKMAN, Paul. Universal Facial Expressions of Emotions. California Mental Health Research Digest, v. 8, n. 4, 1970, p. 151-158.

EKMAN, Paul. Differential Communication of Affect by Head and Body Cues. Journal of Personality and Social Psychology, v. 2, n. 5, 1965, p. 726-735.

EKMAN, Paul; FRIESEN, Wallace V. A. Unmasking the face: A Guide to Recognizing Emotions from Facial Expressions. Los Altos, California: Malor Books (e-book), 2003.

EKMAN, Paul; FRIESEN, Wallace V. A New Pan-Cultural Facial Expression of motion. Motivation and Emotion, v. 10, n. 2, 1986, p. 159-168.

EKMAN, Paul; FRIESEN, Wallace V. A Tool for the Analysis of Motion Picture Film or Video Tape. American Psychologist, v. 24, n. 3, 1969, p. 240-243.

EKMAN, Paul; SORENSON, E. R.; FRIESEN, Wallace V. Pan-Cultural Elements in Facial Display of Emotions. Science, n. 164, 1969, p. 86-88.

GERLING, Cristina C.; SANTOS, Regina A. T. dos. As conexões entre música e emoção sob perspectivas psicológicas, filosóficas e estéticas. In: Estudos sobre motivação e emoção em cognição musical. Rosane C. de Araújo e Danilo Ramos (org.). Curitiba: UFPR, 2015, p. 13-44.

GERLING, Cristina C.; SANTOS, Regina A. T. dos; DOMENICI, Catarina. Reflexões sobre interpretações musicais de estudantes de piano e a comunicação de emoções. Música Hodie. v.8, n. 1, 2008, p. 11-25.

GERLING, Cristina C.; DOMENICI, Catarina; SANTOS, Regina A. T. dos. As intenções e percepções da emoção nas interpretações musicais de um Prelúdio de J.S. Bach. Anais do SIMCAM4 - IV Simpósio de Cognição e Artes Musicais: Aspectos multidisciplinares. São Paulo: USP/FFCLH, 2008, p. 28-34. 
GUSE, Cristine B. Vozes em conversa/notas de programa: Cantos - Tim Rescala (1994). In: Retratos da canção. São Paulo: Sesc Ipiranga, 2006, p. 4 (nota de programa).

HAGA, Egil. Correspondences Between Music and Body Movement. Oslo: University of Oslo, Faculty of Humanities, 2008. (Doctorate Dissertation in Music).

HAMILL, J.; KNUTZEN, K. M. Bases biomecânicas do movimento humano. São Paulo: Manole, 2008.

HERR, Martha Mudanças nas Normas para a boa pronúncia da língua portuguesa no canto e no teatro no Brasil: 1938, 1956 e 2005. Per Musi, v. 15, Belo Horizonte: UFMG, 2007, p. 35-40.

HERR, Martha Um Modelo para Interpretação da Canção Brasileira nas Visões de Mário de Andrade e Oswaldo de Souza. Música Hodie, v. 4, Goiânia: UFG, 2004, p. 27-37.

HERR, Martha As Normas da boa pronúncia do português no canto e no teatro: comparando os documentos de 1938 e 1958. ARTEunesp, v. 16, São Paulo: Unesp, 2003, p. 25-39.

HERR, Martha; MATTOS, Wlad; KAYAMA, Adriana. Brazilian Portuguese: Norms for Lyric Diction. Journal of Singing, v. 65, nov-dez 2008, p. 195-211.

HERR, Martha; MATTOS, Wlad; RUBIM, Myrian; KAYAMA, Adriana; CARVALHO, Flávio; MONTEIRO DE CASTRO, Luciana; PEDROSA DE PÁDUA, Mônica. PB Cantado: Normas para a Pronúncia do Português Brasileiro no Canto Erudito. Revista Opus, v. 13, Porto Alegre: ANPPOM, 2008, p. 16-38.

LABAN, Rudolf. Domínio do movimento. Org. e ed. por Lisa Ullmann. Trad. de Anna Maria Barros de Vecchi e Maria Silvia Mourão Netto. Apresentação de Maria Duschenes. São Paulo: Summus Editorial, 1978.

LACERDA, Marcos; BOSCO, Francisco. A XXI Bienal de Música Brasileira Contemporânea. Prefácio do catálogo. In: https://tinyurl.com/tker6ge. Rio de Janeiro: MINC/Funarte, 2015, p. 3. (catálogo).

MAGILL Richard A. Aprendizagem motora: conceitos e aplicações. 5 ed. São Paulo: Edgard Blucher, 2000.

MAUS, Fred Everett. Music as narrative. Indiana Theory Review, v. 12, 1991, p. 1-34.

MERRELL, Floyd. Charles Sanders Peirces's Concept of the Sign. In: The Routledge Companion to semiotics and linguistics. Paul Cobley (org.). Londres: Routledge, 2001, p. 28-39.

MORAES, Raquel R. de. Aprendizagem inventiva musical: Uma sonorofabulação. Tese de Doutorado em Educação. Vitória: UFES, 2017.

PACHECO, Claudia de O. L. M.; MARÇAL, Márcia; PINHO, Sílvia M. R. Registro e cobertura: arte e ciência no canto. Revista CEFAC: Speech, Language, Hearing Sciences and Education Journal, v.6, n. 4, São Paulo, out.-dez. 2004, p. 429-435.

PAWLIK, Johannes. Goethe Farbenlehre. Köln: M. Dumont Schauberg, 1974.

PEIRCE, Charles S. Semiótica. Tradução de José T. Coelho Neto. 3 ed. São Paulo: Perspectiva, 2005. 
PLAZA, Julio. Tradução intersemiótica. Coleção Estudos, n. 93. São Paulo: Perspectiva, 2003.

RAMOS, Danilo; BUENO, José Lino Oliveira. A Percepção de emoções em trechos de música ocidental erudita. Per Musi, n. 26. Belo Horizonte: 2012, p. 21-30.

RENGEL, Lenira P. Dicionário Laban. Dissertação de Mestrado. Campinas: Unicamp, 2001.

RESCALA, Tim. Re: Cantos. E-mail de Tim Rescala a Fausto Borém, Rio de Janeiro, 22 de novembro de 2018.

RUSSELL, James A. Curriculum $2019 . \quad$ In: https://www.bc.edu/content/dam/bc1/schools/mcas/psych/pdf/cv/cv_russell_2019_nov.pdf. 2019. (Acesso em 2 de junho, 2020).

RUSSELL, James A. A Circumplex Model of Affect. Journal of Personality and Social Psychology. Vancouver. v. 39, n. 6, 1980, p. 1161-1178.

RUSSELL, James A.; BARRETT, Lisa F. Core Affect, Prototypical Emotional Episodes, and Other Things Called Emotion: Dissecting the Elephant. Journal of Personality and Social Psychology, v. 76, n. 5, 1999, p. 805-819.

SALZMAN, Eric; DÉSI, Thomas. The New music theater: Seeing the voice, hearing the body. New York: Oxford University Press, 2008.

SAMPAIO, João L. Morre a soprano Martha Herr. In: Música clássica e ...um pouco de tudo. Blog João Luis Sampaio. Estadão, https://tinyurl.com/uqmnkra. 1 nov. 2015.

SCHENKER, Heinrich. Harmony. Oswald Jonas (ed.), tradução de Elisabeth M. Borgese. Chicago: UCP, 1954.

SCHMIDT, Richard A. Aprendizagem e performance motora: dos princípios à prática. São Paulo: Movimento, 1993.

SCHMIDT, Richard A.; WRISBERG, Craig A. Aprendizagem e performance motora: uma abordagem da aprendizagem baseada no problema. Tradução de Ricardo Petersen. 2. ed. São Paulo: Artmed, 2001.

SEYMOR, Chatmanm. Story and Discourse. Ithaca: Cornell University Press, 1978.

SIDNEY, Eduardo. Memória Globo: Escolinha do Professor Raimundo. 2016. In: https://tinyurl.com/uvu4cc7. Acesso em 10 de maio de 2016.

STERN, Daniel. The Interpersonal World of the Infant. New York: Basic books, 1985. 


\section{Referências de vídeos e partitura}

HERR, Martha. Vozes em Conversa. CD de vídeo. $42^{\circ}$ Festival Música Nova. Obras de Eduardo Guimarães Álvares, Almeida Prado, Achille Picchi, Edson Zampronha, L. C. Csekö, Ilza Nogueira, Gilberto Mendes, Willy Corrêa de Oliveira, Jocy de Oliveira e Tim Rescala. Direção cênica e iluminação de Iacov Hilel. Direção de fotografia de Carlos Travaglia. São Paulo: Pipoca Cine Vídeo, 2008.

HERR, Martha; CAICEDO, Patricia. Patricia Caicedo Interviews Dr. Martha Herr Part I. Vídeo de 9 minutos e 1 segundo, postado em 30 de jul. de 2010 por mundoartsmusic. Disponível em https://youtu.be/U_FHUakdLN8. 2010.

HERR, Martha; RESCALA, Tim. Martha Herr interpreta Cantos de Tim Rescala. Com Martha Herr (canto e cena); Tim Rescala (composição), Iacov Hillel (direção cênica e iluminação) e Marcelo Nicolino (direção de vídeo), 2008. In: https:/youtu.be/fXAuku7alIU. Vídeo de 5 minutos e 25 segundos, postado no YouTube por Fausto Borém em 21 de abril de 2016.

RESCALA, Tim. Cantos, para atriz-cantora. Partitura. Rio de Janeiro: Edição do compositor, 1994. 